\title{
Yabancılara Türkçe öğretimi ders kitaplarında bulunan metin altı soruların yenilenmiş Bloom taksonomisine göre analizi ${ }^{1}$
}

Fatih KANA2

\section{E. Zeynep GÜNEY3}

\begin{abstract}
APA: Kana, F.; Güney, E. Z. (2020). Yabancılara Türkçe öğretimi ders kitaplarında bulunan metin altı soruların yenilenmiș bloom taksonomisine göre analizi. RumeliDE Dil ve Edebiyat Araştırmaları Dergisi, (19), 141-161. DOI: 10.29000/rumelide.752222.
\end{abstract}

\section{$\ddot{O} \mathbf{z}$}

Bu çalışmanın amacı, yabancılar için Türkçe öğretimi alanında kullanılan ders kitaplarında bulunan okuma ve dinleme metinlerine ait metin altı soruları yenilenmiş Bloom taksonomisine göre analiz etmektir. Bu amaca bağlı olarak seçilen yabancılara Türkçe öğretimi ders kitaplarındaki her bir temanın okuma ve dinleme metinleri; metin türü, metin sayısı, soru sayısı ve her bir metnin ortalama soru sayısı tespit edilecek şekilde incelenmiştir. Ayrıca incelenen okuma ve dinleme metinlerinde bulunan metin altı sorular yenilenmiş Bloom taksonomisine uygun olarak sınıflandırılmış ve metin altı soruların alt düzey ile üst düzey bilişsel becerilere ne derece hizmet ettiği belirlenmiştir. Çalışmada nitel araştırma desenlerinden “doküman analizi”nden yararlanılmıştır. Araştırmanın çalışma grubunu "İstanbul Yabancılar İçin Türkçe Öğretim Seti” ile "Yedi İklim Türkçe Yunus Emre Enstitüsü Öğretim Seti” oluşturmaktadır. Çalışmanın bulgularına bakıldığında her iki sette de metin türlerinin temalara eşit şekilde dağılmadığı, metin türü bakımından çeşitliğin az olduğu ve metinlerin ortalama soru sayılarında farklılıklar olduğu görülmüştür. Her bir temada bulunan okuma ve dinleme metinlerindeki metin altı soruların "İstanbul Yabancılar İçin Türkçe” setinde daha çok alt düzey bilişsel becerilere, "Yedi İklim Türkçe Yunus Emre Enstitüsü Öğretim Seti”nde ise buna nazaran soruların alt düzey ve üst düzey bilişsel becerilere daha eşit oranda hizmet ettiği tespit edilmiştir. Ayrıca tek bir metin altında bulunan soruların "İstanbul Yabancılar İçin Türkçe" setinde çoğunlukla tek bir beceriyi örneklendirirken, "Yedi İklim Türkçe Yunus Emre Enstitüsü Öğretim Seti”nde soruların kendi içinde farklılaştığı ve alt düzey ile üst düzey bilişsel becerileri birlikte örneklendirdiğ tespit edilmiştir. Ancak her iki kitapta da tek bir metin altındaki soruların alt düzey bilişsel basamaklardan üst düzey bilişsel basamaklara doğru kademeli şekilde hazırlanmadığı görülmüştür. Buna ek olarak taksonominin en üst düzey basamağı olan “yaratmak” basamağına uygun soru azlığ dikkate değer bulunmuştur.

Anahtar kelimeler: Ders kitapları, metin altı sorular, yabancılara Türkçe öğretimi, yenilenmiş Bloom taksonomisi

Bu araștırma, ikinci yazarın yüksek lisans tezinden üretilmiștir.

Dr. Öğr. Üyesi, Çanakkale Onsekiz Mart Üniversitesi, Eğitim Fakültesi, Türkçe ve Sosyal Bilimler Bölümü, Türkçe Eğitimi ABD (Çanakkale, Türkiye), fatihkana@hotmail.com, ORCID: oooo-0oo2-1087-4081 [Makale kaylt tarihi: 14.05.2020kabul tarihi: 20.06.2020; DOI: 10.29000/rumelide.752222]

Bilim Uzmanı , Çanakkale Onsekiz Mart Üniversitesi, Eğitim Bilimleri Enstitüsü, Türkçe ve Sosyal Bilimler Eğitimi Bölümü (Çanakkale, Türkiye), esmazeynepg@gmail.com, oooo-00o3-1573-1247. 
The analysis according to renewed Bloom taxonomy of the questions under the texts in the course books prepared for teaching Turkish as a foreign language / F. Kana, E. Z. Güney (pp. 141-161)

\title{
The analysis according to renewed Bloom taxonomy of the questions under the texts in the course books prepared for teaching Turkish as a foreign language
}

\begin{abstract}
The aim of this study is to analyze the questions under the texts of reading and listening texts in textbooks used in the field of Turkish teaching for Foreigners according to the renewed Bloom Taxonomy. For this purpose, reading and listening texts of each theme in the selected textbooks teaching Turkish to foreigners; text type, number of text, number of questions and average number of questions of each text were examined in a way to determine. In addition, the questions under the texts in the reading and listening texts examined were classified and in accordance with the renewed Bloom Taxonomy and was determined that the questions under the texts what extent serve to the low and high level cognitive skills. In the study, case study, which is one of the qualitative research methods, was utilized. The universe of the study consists of textbooks teaching Turkish for foreigners, and the sampling consists of "İstanbul Yabancılar İçin Türkçe Öğretim Seti” and "Yedi İklim Türkçe Yunus Emre Enstitüsü Öğretim Seti”. When the findings of the study were examined, it was seen that the text types were not equally distributed to the themes in both sets, the variety of text types was low and there were differences in the average number of questions of the texts. While the text in the reading and listening texts in each of the themes served more low level cognitive skills in the Türkçe Istanbul for Foreigners "set of the questions under the texts, Seven Climate Turkish Yunus Emre Institute Teaching Set was found to serve the questions equally and lower level cognitive skills. In addition, while the questions under a single text mostly exemplify a single skill in the "Istanbul for Foreigners" set, it was found that the questions in the Seven Climate Turkish Yunus Emre Institute Teaching Set differentiated in themselves and exemplified lower and upper level cognitive skills together. However, in both books, it was observed that the questions under a single text were not prepared gradually from the lower cognitive steps to the higher cognitive steps. In addition, the lack of questions appropriate to the "create" level, which is the highest level of taxonomy, was noteworthy.
\end{abstract}

Keywords: The questions under the texts, the renewed bloom taxonomy, teaching Turkish to foreigners, textbooks

\section{Giriş}

Dil; düşüncelerin, duyguların ve isteklerin, kitleler arasında ses ve anlamca ortak olan unsurları ve kurallarından hareketle başkalarına aktarılmasını sağlayan çok yönlü ve çok gelişmiş bir dizge olarak tanımlamaktadır (Aksan, 1998, s. 55). Dil, bir toplumun anlaşma vasıtası olmakla beraber kültür taşıyıcısı olma görevini de üstlenir (Özbay, 2002). İnsanı diğer bütün canlılardan ayrılan önemli farklılığından biri de kendi ana dili dışında başka dilleri de öğrenebilmesidir (Gün, Akkaya ve Kara, 2014). Ana dilinden başka yabancı bir dili öğrenme, o kültürü öğrenmenin ve onu anlamanın en kolay ve mükemmel yollarından biridir (İşcan, 2012).

Ĕ̈itimin amaçlarını gerçekleştirmek için kullanılan ders kitapları, öğretim araç gereçlerinden biri ve birçok durumda da tek öğretim materyalidir (Halis, 2002, s. 51). Ders kitapları, "öğrenme-öğretme esnasında neler öğrenileceğini ve neler öğretileceğini etkileyen bir kaynak” olarak kullanılmaktadır (Küçükahmet, 2003, s. 18). Demirel, kitapların "dil öğrenme-öğretme aşamasının ayrılmaz görsel araçları olduğunu ifade etmektedir (1993, s. 91). Ders kitaplarının kalitesini artıran en önemli özelliklerinden biri, ölçme ve değerlendirme bölümlerinin yeterli ve çeşitli oluşudur. Ölçme ve 
değerlendirmeyi eğitim-öğretim sürecinin her safhasında canlı kılan ve bu sürece doğru yön veren bir değerlendirme ders kitabının önem ve kalitesinin artırılmasını sağlamaktadır (Göçer, 2007, s. 30). Öğrencilerin, öğrenme ve öğretme sürecinde edindikleri kazanımların hangi düzeyde gerçekleştiğini ve yapılan uygulamaların etkili olup olmadığını belirlemede ölçme-değerlendirme son derece önemlidir (Yaşar, 2018).

"Metin, belli bir bildirişim bağlamında bir ya da birden çok kişi tarafından sözlü ya da yazılı olarak üretilen bir dil dizgesi bütünüdür" (Günay, 2007, s. 44). "Metin; edinilmiş bilgilerin, duyguların, düşüncelerin farklı şekil, anlatım ve noktalama özelliklerine göre yer aldığı yapılardır. Metinlere öğelerin yerleştirilmesi rastgele sıralama şeklinde değil, mantıklı ve anlamlı bir düzenleme ile gerçekleştirilir" (Güneş, 2013, s. 606). "Metinleri, yapısını meydana getiren öğelerin birbirlerine bağdaşık ve tutarlı bağlandığı, belli bir amaçla üretilmiş, başlangıcı ve bitişi belli olan anlamlı bir bütünden oluşan ürün olarak tanımlanabilir" (Onursal, 2003, s. 126). Yabancılara Türkçe öğretimi alanında çeşitli sınıflandırmalar yapılsa da genel anlamda anlatı (öyküleyici), bilgilendirici ve şiir olmak üzere üç farklı metin türü karşımıza çıkmaktadır.

Yabancılar için Türkçe ders kitaplarında bulunan metinlerin altında, işlenen metnin öğrenciler tarafından anlaşılıp anlaşılmadığını ölçen, cevaplarken düzeye ait kazanımlarını ölçen metin altı sorular yer almaktadır. Metin altında yer alan soruların çeşitli sınıflandırmaları bulunmaktadır. $\mathrm{Bu}$ sınıflandırmalar; sorunun kaynağı, cevabın metin içinde olması, bilişsel süreçlerin yer alma şekli, nasıl hazırlandığı (klasik sorular, doğru-yanlış soruları, doldurmalı sorular, çoktan seçmeli sorular, eşleştirmeli sorular ...) gibi unsurlara dikkat edilerek yapılmaktadır. Soruların amaçlarına göre; tanımlama, ana fikir, görüş bildirme, neden-sonuç, listeleme, örneklendirme, karşılaştırma-kıyaslama, özetleme, ödev, sonucu tahmin etme, karakterize etme, uygulama ve değerlendirme gibi türlere ayrıldı̆̆ görülmektedir (Kuzu, 2013).

Bloom tarafından 1956'da hazırlanan Yenilenmiş Bloom Taksonomisi, eğitimde düşünme becerilerinin sınıflandırılmasında gösterilen önemli bir kaynaktır. Taksonomi, kavramların basitten karmaşığa doğru ve her bir basamağın diğerinin koşulu olacak şekilde sınıflandırmasıdır. (Sönmez, 2007). Altı basamaktan oluşan taksonominin en alt basamağında bilgi basamağı yer almaktadır. Bilgi basamağını kavrama, uygulama, analiz, değerlendirme ve yaratma basamakları izlemektedir. Bilgi, kavrama ve uygulama alt seviyeler olarak kabul edilirken, analiz, değerlendirme ve yaratma üst düzey bilişsel seviyeler olarak kabul edilmektedir. Sonraki basamağa ait davranışın öğrenilebilmesi için kendinden önceki basamakta yer alan davranışların kazanılmış olması gerekmektedir. Dolayısıyla bir basamak, kendinden sonra gelen üst basamağın ön koşulu sayılmaktadır (Arı, 2013).

Anderson ve diğer uzmanlar, Bloom Taksonomisi’ndeki çok eleştiri alan çelişkiler ile eksiklikleri ortadan kaldırmak ve taksonomiyi daha modern hâle getirmek için birtakım yenilik ve düzenlemelerde bulunmuşlardır. Çok köklü bir değişime uğramayan bu yeni taksonomiyi "Revize Edilmiş Bloom Taksonomisi (Revised Bloom Taxonomy)” olarak adlandırmışlardır (Bekdemir ve Selim, 2008). Bloom'un öğrencileri Anderson ve Krathwohl başkanlığında toplanan çalışma grubu tarafından yenilenen taksonomide temelde iki yenilik getirmiştir: Birincisi, altı kategorinin isimleri isimden eyleme dönüştürülmüş; ikincisi de üstteki iki basamağın yerleri değiştirilerek, sentez basamağı çıkarılıp yerine yaratma basamağı eklenmiştir (Durukan ve Demir, 2017). Yenilenmiş taksonomide en dikkate değer değişiklik, bir boyuttan iki boyuta geçilmesidir. Eski taksonomide bilgi basamağında hem isim hem eylem hallerinin birlikte oluşu öğrenciden eylem durumu için bilgiyi hatırlayabilmesinin ya da tanımlayabilmesinin beklenmesine yol açmaktaydı. Revize edilmiş taksonomide isim ve eylem formu 
ayrılarak iki boyutta ele alınmıştır. Bunlar, bilgi boyutu ve bilişsel süreç boyutudur (Amer, 2006'dan aktaran Arı, 2011). Yenilenmiş taksonominin bilişsel alanı, bilişsel süreç boyutu olarak da asıl taksonomiden farlılıklar göstermektedir. Bilişsel süreç boyutunda bilginin kullanım şekli incelenmektedir. Hatırla, anla, uygula, analiz et, değerlendir ve yarat basamaklarından oluşmaktadır (Arl, 2013, s. 263).

Tarihin en eski dönemlerinden beri yabancılara Türkçe öğretiminin en temel materyallerinden biri ders kitapları olmuştur (Gün, Akkaya ve Kara, 2014). Yabancı dil olarak Türkçe öğretimi ders kitapları, bu güne değin pek çok araştırmanın konusu olmuştur. Kitaplar gerek içerik, gerek metinler, gerekse kelime öğretimi gibi hususlarda incelenerek çalışmalara konu olmuştur. Bu çalışmanın temelini oluşturan Bloom taksonomisi, araştırmacılar tarafından pek fazla ele alınmamış; özellikle de yabancılara Türkçe eğitimi noktasında göz ardı edilmiştir. Halbuki öğretmenlerin ve ders kitaplarının amacı salt ezber bilgiler sunmak olmamalı; öğrencilere okuduğunu anlamlandırmasını sağlayan, onları düşünmeye sevk eden, kendi fikirlerini kendi cümleleri ile söyleyebilmelerine olanak veren, yaratıcılıklarını destekleyen etkinlik ve örnekler de sunulmalıdır. Ders kitaplarında yer alan metinler, metinlere ait sorular aracılı̆̆ıla tüm bunları gerçekleştirmek mümkün olmaktadır. Böylelikle öğrenciler okudukları ya da dinledikleri metni hem çok daha iyi anlamlandırabilmekte hem de bu sorulardan hareketle yeni problem durumları yaratabilmektedir. Yabancılar için Türkçe öğretimi ders kitaplarının incelendiği pek çok çalışma bulunmaktadır (Bölükbaş ve Keskin, 2010; Erol, 2014; Göçer, 2007; Toprak, 2011). Yine yenilenmiş Bloom taksonomisine göre soru ve etkinliklerin analiz edildiği çalışmalar da mevcuttur (Delibaş, 2013; Oktay, 2015; Korkmaz ve Ünsal, 2016). Ancak bu çalışmalar özellikle de yabancılara Türkçe öğretimi alanında oldukça sınırlıdır. Çalışmanın bu alanda hazırlanacak ders kitaplarına ışık tutması ve özellikle de hazırlanacak sorularda bilişsel süreçlere dikkat çekmesi bakımından alanyazına katkı sağlaması beklenmektedir.

Araştırmanın problem cümlesi "Yabancılara Türkçe öğretiminde kullanılan ders kitaplarındaki metin altı sorular hazırlanırken yenilenmiş Bloom taksonomisi dikkate alınma düzeyi nedir? Metin türlerinin bu dağılımda yeri nedir?” olarak belirlenmiştir.

Araştırmanın alt problemleri şu şekilde sıralanmıştır:

Yabancı dil olarak Türkçe öğretiminde kullanılan ders kitaplarındaki metin altı sorular seviyeye uygun bilişsel basamağ örneklendirmekte midir?

Yabancı dil olarak Türkçe öğretiminde kullanılan ders kitaplarındaki metinlerin türleri nelerdir? Metin türleri kitap içerisinde dengeli şekilde bulunmakta mıdır?

\section{Bölüm II: Yöntem}

$\mathrm{Bu}$ bölümde; kullanılan araştırma modeli, çalışma grubu, araştırmada kullanılan veri verilerin çözümlenmesi ve analizi hakkında bilgi verilmiştir.

\section{Araşturmanın modeli}

Bu çalışmada nitel araştırma yöntemlerinden durum çalışması deseni kullanılmıştır. Nitel araştırmalar önceden belirlenen bir araştırma konusu ile ilgili "ne, nasıl, niçin" gibi sorulara yanıt arayan katılımcıların bakış açısına direkt olarak ve kendi doğal ortamlarında ulaşılan, sonuçların sözel şekilde ifade edildiği araştırma türleridir (Büyüköztürk, Çakmak, Akgün, Karadeniz ve Demirel 2014, s. 240; 
Ylldırım ve Şimşek, 2008). İlgili araştırmada seçilen İstanbul Yabancılar İçin Türkçe Öğretim seti ile Yedi İklim Türkçe öğretim setinin tüm kitaplarının okuma ve dinleme metinlerinde yer alan metin altı sorular, yenilenmiş Bloom taksonomisine göre çözümlenmiş ve taksonomisinin bilişsel süreç basamaklarının nasıl bir eğilim gösterdiği belirlenmeye çalışılmıştır.

\section{Çalışma grubu}

Araştırmanın çalışma grubunu İstanbul Yabancılar için Türkçe ve Yedi İklim Türkçe adlı ders kitapları oluşturmaktadır. Araştırmanın çalışma grubu, İstanbul Yabancılar için Türkçe öğretim setinin A1, A2, B1, B2 ve C1/+ ders kitapları ile Yedi İklim Türkçe öğretim setinin A1, A2, B1, B2, C1 ve C2 ders kitapları ile sinırlandırılmıştır.

\section{Verilerin analizi}

Toplanan veriler içerik analizi yöntemiyle incelenmiştir. İçerik analizi, belirlenen kurallara bağlı olarak yapılan kodlamalarla metnin bazı sözcüklerinin daha küçültülmüş kategorilere göre özetlendiği sistemli ve tekrarı mümkün olan bir tekniktir (Büyüköztürk vd., 2014, s. 240). İçerik analizi araştırmanın için toplanan verilerin kodlanarak sınıflama-tanımlama ve tanımlama-sınıflama şeklinde devam etmesine dayanır (Glesne, 2012). İçerik analizinin temelinde birbiriyle benzer bulguları belirli kavramlar ve temalar çerçevesinde biraraya getirerek okuyucunun anlayabileceği şekle getirip yorumlamak vardır (Ylldırım ve Şimşek, 2008).

Verilerin toplanması iki aşamada gerçekleştirmiştir. İlk aşamada öğretim setlerinin yalnız ders kitapları tek tek incelenmiş ve tema başında belirlenen okuma ve dinleme metinlerinin sayısı belirlenmiştir. Her iki öğretim setinde de yer alan harici okuma metinleri ve serbest okuma metinleri çalışmanın dışında tutulmuştur. Metinler öncelikle türlerine göre sınıflandırılmış ardından aynı türden metinlere ait soru sayıları tablolaştırılmıştır. Ortaya çıkan tablo ile metin türüne ait ortalama soru sayısı belirlenmiştir. İkinci aşamada temalar tek tek incelenerek temaya ait okuma ve dinleme metinleri belirlenmiş ve her bir metnin altında yer alan sorular taksonominin bilişsel süreçlerine göre çözümlenmiştir. Setin içinde yer alan tüm seviyelerdeki ders kitapları bu şekilde önce tema sonra tüm kitap şeklinde incelenmiş ve soruların sayısı ait olduğu basamağa girilmiştir. Böylelikle bilişsel basamakların hangi eğilimde yer aldığı tablolaştırılmıştır.

İstanbul Yabancılar İçin Türkçe A1 Ders Kitabı'nda yer alan 6 temaya ait 35 metinde yer alan toplam 388 metin altı sorusunun 259'u hatırlama, 37'si anlama, 28'i uygulama, 63'ü analiz ve 1 tanesi yaratma basamağına uygun bulunmuştur. Değerlendirme basamağına ait soru örneği ile karşlaşılmamıştır. İstanbul Yabancılar İçin Türkçe A2 ders kitabında bulunan 6 temaya ait toplam 36 metinde yer alan 394 sorunun 310' hatırlama, 50'si anlama, 14'ü uygulama, 18’i analiz, 2'si değerlendirme basamağına aittir. Yaratma basamağını örneklendiren soruya ise rastlanılmamıştır. İstanbul B1 ders kitabından elde edilen bulgulara göre, kitapta yer alan 6 tema içerisindeki 36 metne ait 385 metin altı sorusunun 261’i hatırlama, 40'ı anlama, 28'i uygulama, 48'i analiz, 8'i değerlendirme basamağında yer alırken yaratma basamağını örneklendiren soru bulunmamaktadır. İstanbul Yabancılar İçin Türkçe B2 ders kitabı metin altı soruların analizinin yer aldığı 9 numaralı tabloya bakıldığında 36 metne ait tespit edilen 356 sorudan 234'ünün hatırlama, 45’inin anlama, 25’inin uygulama, 41’inin analiz ve 11'inin değerlendirme sürecini örneklendirdiği görülmektedir. İncelenen metinlerde yaratma düzeyine ait soru türüne rastlanmamıştır. İstanbul C1/+ ders kitabından elde edilen verilere göre, 12 tema içerisinde yer alan 72 
The analysis according to renewed Bloom taxonomy of the questions under the texts in the course books prepared for teaching Turkish as a foreign language / F. Kana, E. Z. Güney (pp. 141-161)

metne ait 705 sorunun 325’i hatırlama, 135’i anlama, 54'ü uygulama, 135’i analiz, 51’i değerlendirme ve 5 ’i yaratma basamağına uygun bulunmuştur.

Yedi Íklim A1 ders kitabında bulunan 8 temaya ait 48 metinde yer alan toplam 318 sorudan hatırlama düzeyine ait 285, anlama düzeyine ait 14, uygulama düzeyine ait 11, analiz düzeyine ait 6 ve değerlendirme düzeyine ait 2 soru tespit edilmiştir. Yaratma düzeyine uygun soru ile karşılaşılmamıştır. Yedi İklim A2 ders kitabında elde edilen bulgularına göre 8 temaya ait 48 metinde yer alan toplamda 403 sorudan 204'ü hatırlama, 88’i anlama, 11’i uygulama, 91’i analiz, 8’i değerlendirme ve 1’i yaratma basamağına ait olarak bulunmuştur. Yedi İklim B1 ders kitabında bulunan 8 temadaki 48 metne ait toplam 336 sorunun 179'u hatırlama, 47'si anlama, 4'ü uygulama, 100'ü analiz ve 6'sı değerlendirme basamağına uygun görülmüştür. Yaratma basamağını örneklendiren soru ile karşılaşılmamıştır. Yedi İklim B2 ders kitabından elde edilen bulgulara göre 8 temaya ait 48 metnin içerdiği toplam 547 sorudan hatırlama düzeyine ait 168, anlama düzeyine ait 62, uygulama düzeyine ait 23, analiz düzeyine ait 223, değerlendirme düzeyine ait 70 ve yaratma düzeyine ait 1 soru bulunmaktadır. Yedi İklim $C 1$ ders kitabı verilerinin yer aldığ 1 tablo 16'ya göre, kitap içerisinde bulunan 8 temaya ait 48 metin üzerinde yapılan incelemede metin altı soru sayısı toplam 661 olarak bulunmuştur. Bu sorulardan 284'ü hatırlama, 122'si anlama, 24'ü uygulama, 187'si analiz, 42'si değerlendirme ve 2'si yaratma basamağındadır. Yedi İklim C2 ders kitabından elde edilen bulgulara göre 8 tema içerisindeki 48 metne ait toplam 395 sorunun 141'i hatırlama, 71’i anlama, 38'i uygulama, 79'u analiz, 63'ü değerlendirme ve 3'ü yaratma basamağına uygun görülmüştür.

\section{Bölüm III: Bulgular ve yorum}

Çalışmanın bu bölümünde elde edilen verilerden yararlanılarak yorumlarda bulunulacaktır.

\section{İstanbul Yabancılar İçin Türkçe A1 ders kitabına ilişkin bulgular ve yorum}

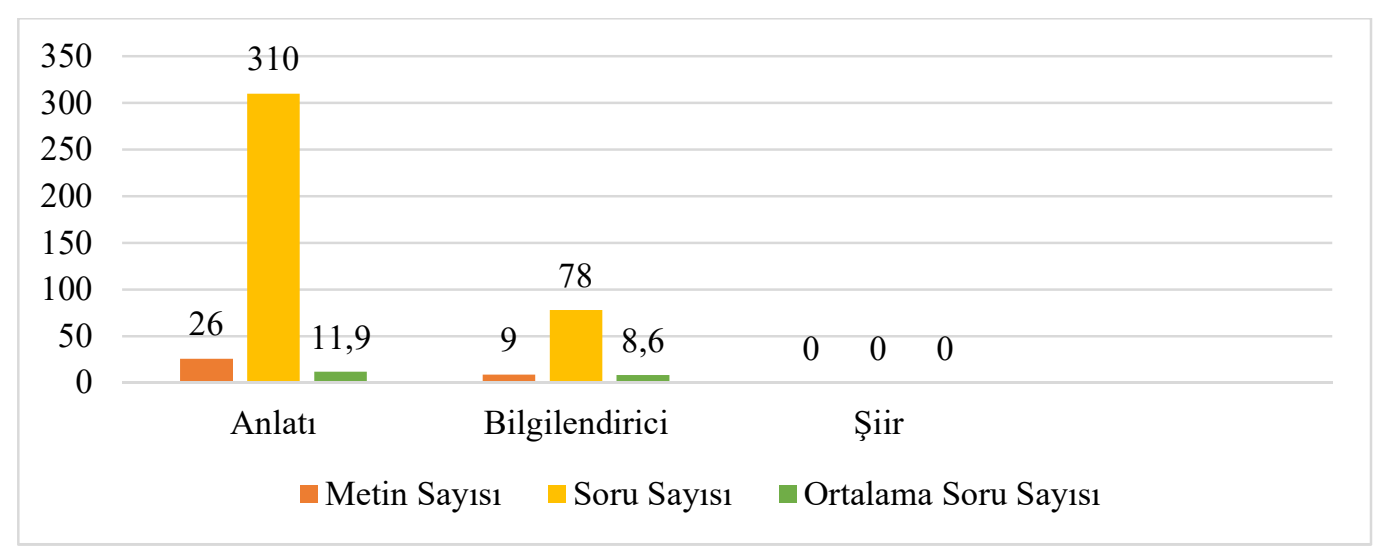

Şekil 1. İstanbul A1 ders kitabı metin türü ve soru sayısının dağılımı

Şekil 1'de İstanbul Yabancılar İçin Türkçe A1 ders kitabına ilişkin metin türleri ve soru sayıları ile ortalama soru sayıları görülmektedir. Anlatı metin türüne ait 26, bilgilendirici metin türüne ait 9 metin tespit edilmiştir. İncelenen A1 ders kitabında tema başında belirlenen okuma ve dinleme türleri incelendiğinde şiir türünde metne rastlanmamıştır. Bu bağlamda anlatı türündeki metinlerin çoğunlukta olduğu göze çarpmaktadır. Dolayısıyla metin türleri dengeli şekilde dağılmamıştır. Soru sayılarına bakıldığında anlatı metin türünde 310, bilgilendirici metin türünde 78 soru bulunmaktadır. Anlatı türünde ortalama soru sayısı 11,9 iken bilgilendirici metinlerdeki ortalama soru sayısı 8,6'dır. 
Soru sayıları incelendiğinde bilgilendirici metin türüne ait soru sayısının azlığı dikkat çekmektedir. Anlatı metinlerinin soru sayısı ise buna göre oldukça yüksek kalmıştır.

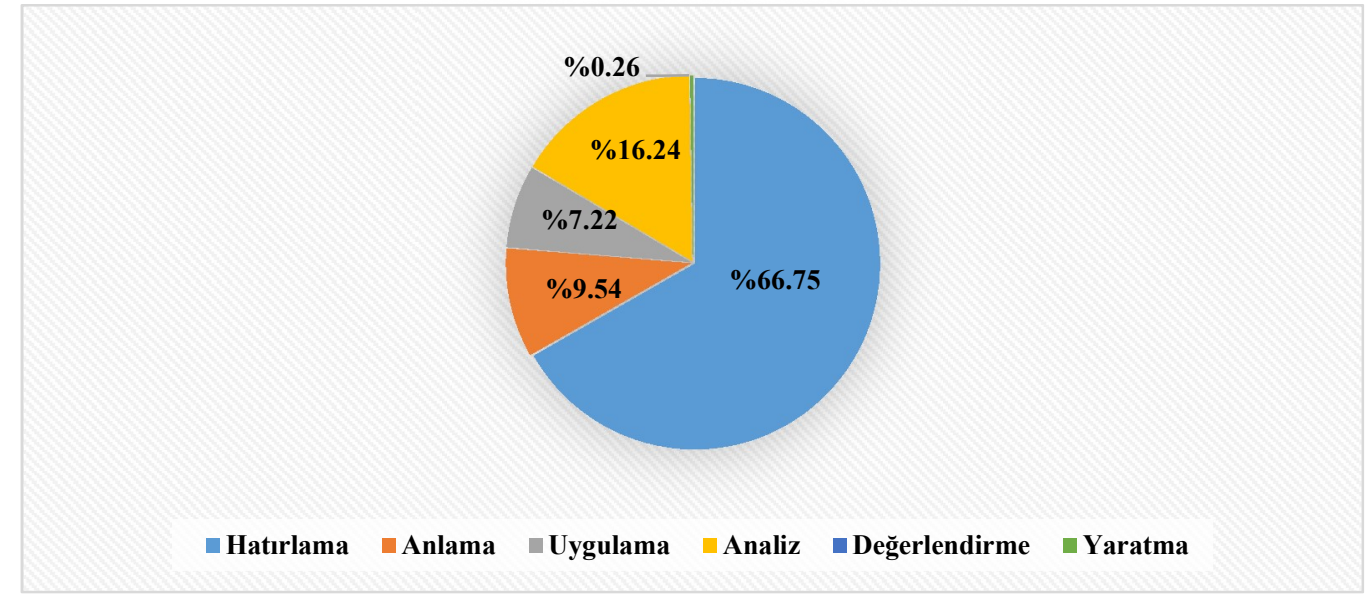

Şekil 2. İstanbul A1 ders kitabı metin altı soruların YBT’ye göre dağılımı

Yukarıdaki şekilde, İstanbul A1 Ders Kitabı'nda yer alan okuma ve dinleme metinlerinde bulunan metin altı soruların taksonomiye göre dağılımı görülmektedir. İncelenen soruların \%66.75’si hatırlama, \%9.54'ü anlama, \%7.22'si uygulama, \%16.24'ü analiz basamağında olduğu görülmektedir. Değerlendirme basamağına ilişkin soru bulunmazken yaratma basamağındaki soru yüzdesi \%o.26 olarak tespit edilmiştir. Elde edilen verilere bakılarak hatırlama düzeyine ait soru yüzdesinin oldukça yüksek olduğu görülmektedir. A1 düzeyi düşünüldüğünde alt düzey bilişsel becerilere uygun soru yüzdesinin fazla olması beklenmektedir. Ancak üst düzey bilişsel basamak becerisi olan analiz düzeyine ait soru yüzdesinin anlama ve uygulama düzeyine ait soru yüzdesine denk olması soruların hazırlanmasında basitten karmaşığa ilkesine dikkat edilmediğini göstermektedir. Yine değerlendirme basamağına uygun soru örneğinin olmayıp yaratma basamağını örneklendiren soru bulunması bu ilkenin göz ardı edildiğinin kanıtı niteliğindedir.

\section{İstanbul Yabancılar İçin Türkçe A2 ders kitabına ilişkin bulgular ve yorum}

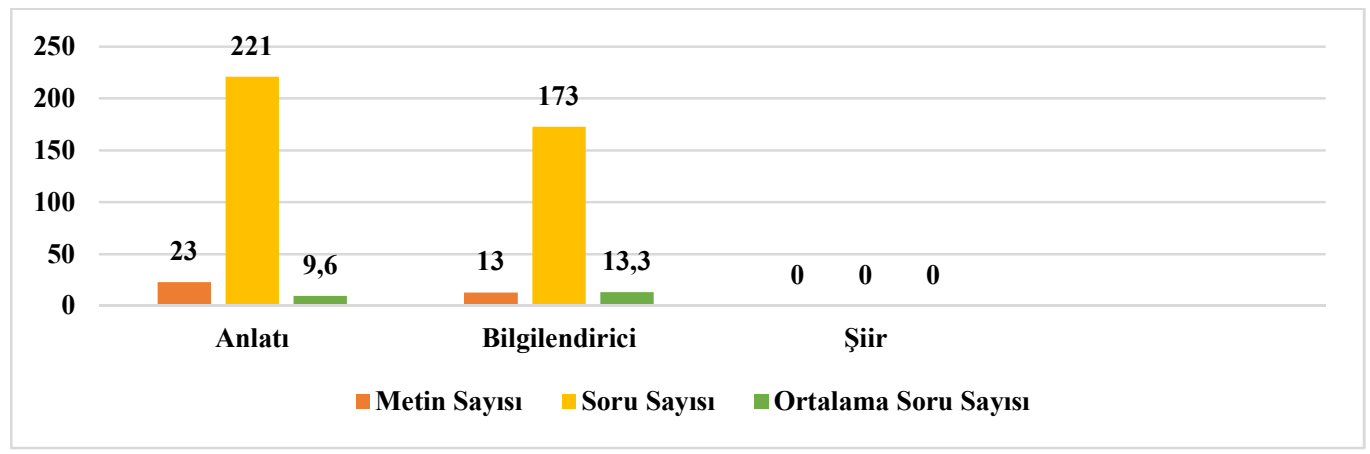

Şekil 3. İstanbul A2 ders kitabı metin türü ve soru sayısının dağılımı

Şekil 3’te göre İstanbul Yabancılar İçin Türkçe A2 ders kitabında anlatı türüne ait 23 metin ve 221 soru sayısı tespit edilmiştir. Anlatı türünü örneklendiren metinlerin ortalama soru sayısı 9,6 olmuştur. Kitapta bulunan bilgilendirici türdeki metinlerin sayısı ise 13’tür. Bu 13 metnin altında 173 soru bulunmuş ve ortalama soru sayısı 13,3 olmuştur. İncelenen dinleme ve okuma metinlerinde şiir türüne 
The analysis according to renewed Bloom taxonomy of the questions under the texts in the course books prepared for teaching Turkish as a foreign language / F. Kana, E. Z. Güney (pp. 141-161)

rastlanmamıştır. Kitapta yer alan metin türlerinin dağılımında dengesizlik mevcuttur. Aynı şekilde daha az olan bilgilendirici metinlerdeki ortalama soru sayısı daha yüksek çıkmıştır. Bu durumda soru sayılarında da dengeli bir dağılım görülmemektedir.

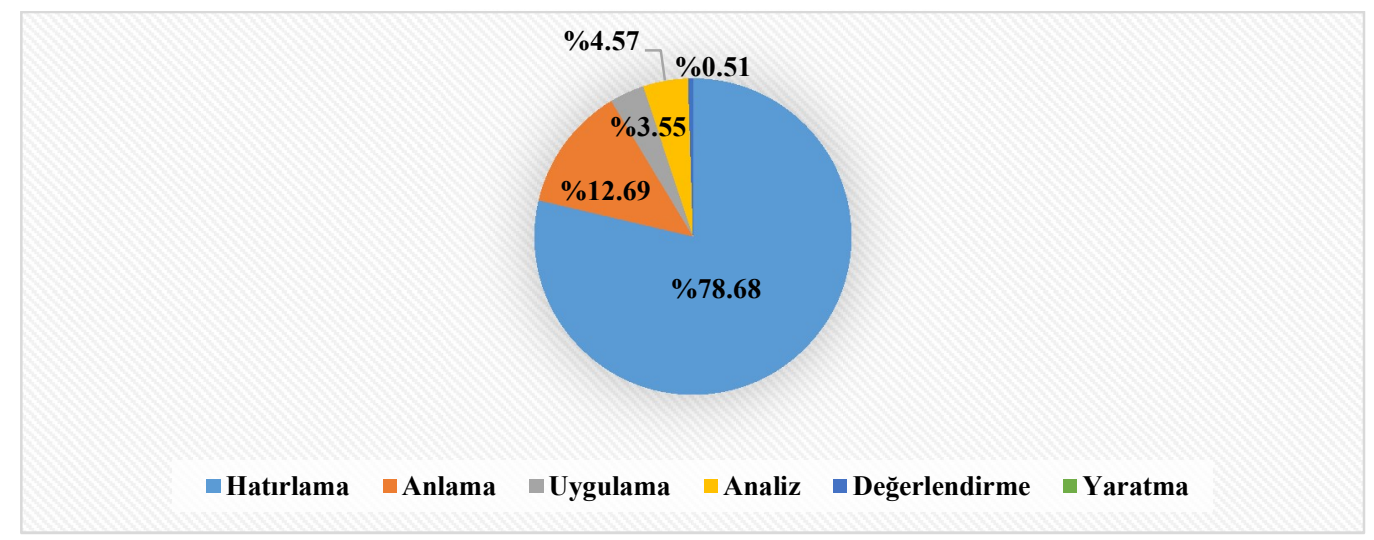

Şekil 4. İstanbul A2 ders kitabı metin altı soruların YBT’ye göre dağılımı

İstanbul A2 Ders Kitabına ait metin altı soruların analizine bakıldığında hatırlama düzeyini örneklendiren soru yüzdesinin \%78.68, anlama düzeyinin \%12.69, uygulama düzeyinin \%3.55; analiz düzeyinin \%4.57, değerlendirme düzeyinin \%o.51 ve yaratma düzeyinin ise \%o olduğu görülmektedir. Bu bağlamda hatırlama düzeyine ait soru yüzdesinin oldukça yüksek olduğu söylenebilmektedir. Buna karşlık üst düzey bilişsel basamak soruları yok denecek kadar azdır. Soruların hazırlanmasında basitten karmaşığa doğru bir sıra izlenmediği de analiz düzeyine ait soruların uygulama düzeyine ait sorulardan fazla olması ile ispatlanabilmektedir. A2 seviyesi göz önüne alındı̆̆ında alt düzey bilişsel basamak becerilerinden anlama ve uygulamanın daha yüksek olması ve alt düzey ile üst düzey beceri soruları yüzdesinin yakın olması beklenmektedir. Buna göre soruların becerilere göre dağılımında da bir denge olmadığını söylemek mümkündür .

\section{İstanbul Yabancılar İçin Türkçe Bı ders kitabına ilişkin bulgular ve yorum}

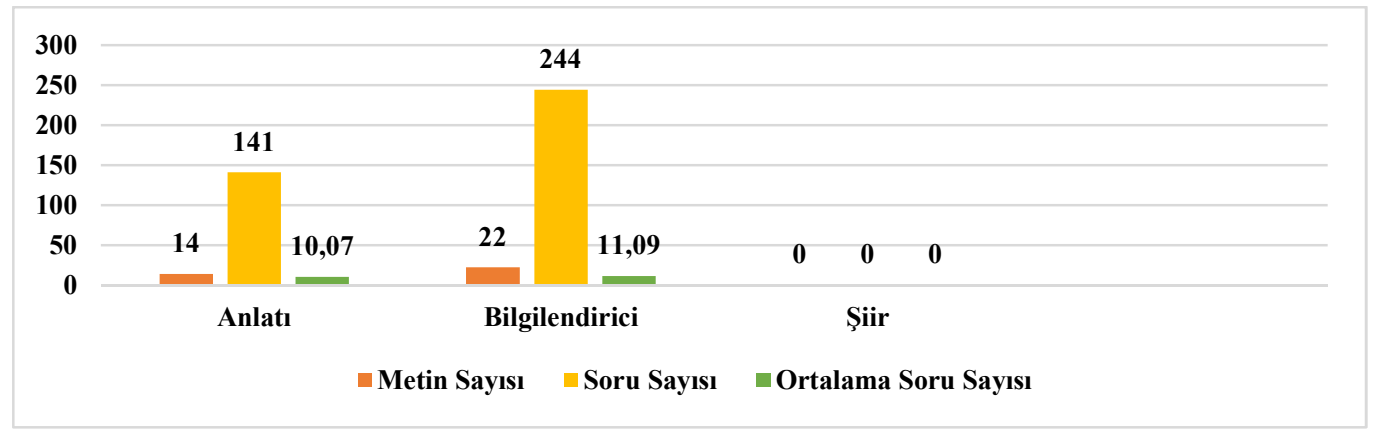

Şekil 5. İstanbul B1 ders kitabı metin türü ve soru sayısının dağılımı

Yukarıdaki şekle göre, İstanbul Yabancılar İçin Türkçe B1 seviyesi ders kitabındaki 36 metinden 14 tanesinin anlatı, 22 tanesinin ise bilgilendirici türde olduğu görülmüsstür. Şiir türünü örneklendiren okuma ya da dinleme metnine ise rastlanmamıştır. Anlatı metinlerine ait soru sayısı 141 ve ortalama soru sayısı 10.07; bilgilendirici metinlere ait soru sayısı 244 ve ortalama soru sayısı 11.09 olmuştur. 
Metin türlerinin dağılımında dengesizlik göze çarpmaktadır. Anlatı türü ve bilgilendirici metin türü soruları karşılaştırıldığında bilgilendirici metin türüne ait soru sayısının daha az kaldığı görülmektedir.

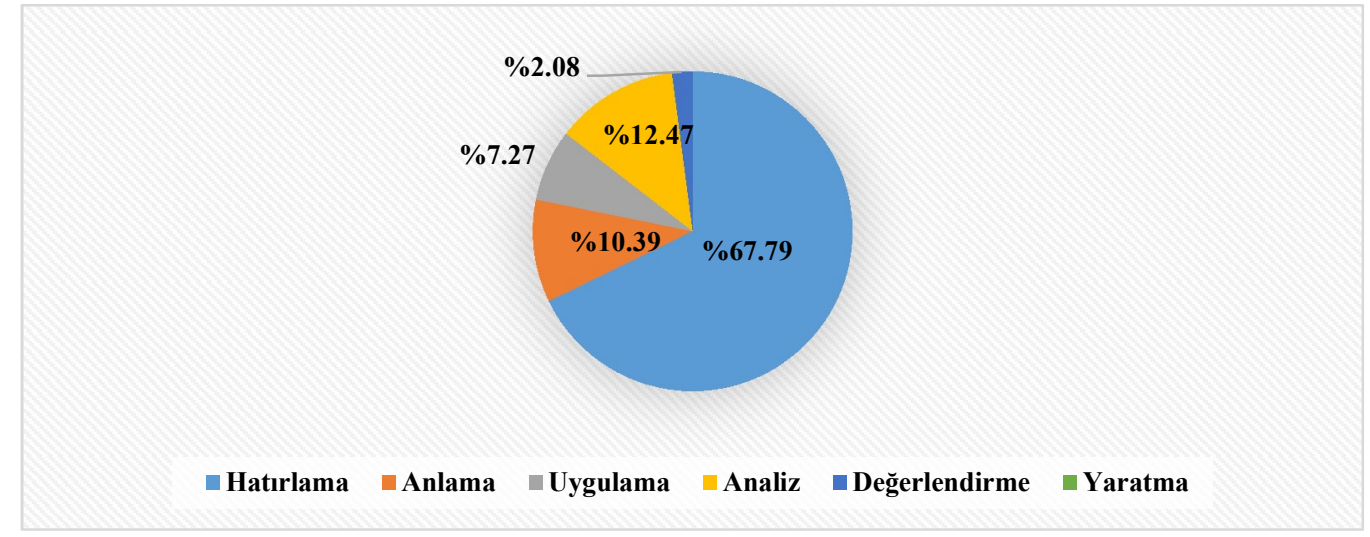

Şekil 6. İstanbul B1 ders kitabı metin altı soruların YBT’ye göre dağılımı

Yukarıdaki şekle göre İstanbul B1 Ders Kitabı'nda bulunan soruların taksonomiye hatırlama düzeyi soru yüzdesi \%67.79, anlama düzeyi \%10.39, uygulama düzeyi \%7.27, analiz düzeyi \%12.47, değerlendirme düzeyi \%2.08 ve yaratma düzeyi \%o düzeyindedir. Elde edilen verilere bakıldığında B1 düzeyinden beklenenin aksine hatırlama düzeyine ilişkin soru yüzdesinin oldukça yüksek olduğunu söylemek mümkündür. Gelinen öğrenme düzeyine göre soruların üst düzey bilişsel becerileri harekete geçirecek nitelikte olması beklenmektedir. Ancak elde edilen sonuçlar tam aksini göstermektedir. Özellikte yaratma basamağına dair soru örneğinin bulunmayışı bir eksiklik olarak göze çarpmaktadır.

\section{İstanbul Yabancılar İçin Türkçe B2 ders kitabına ilişkin bulgular ve yorum}

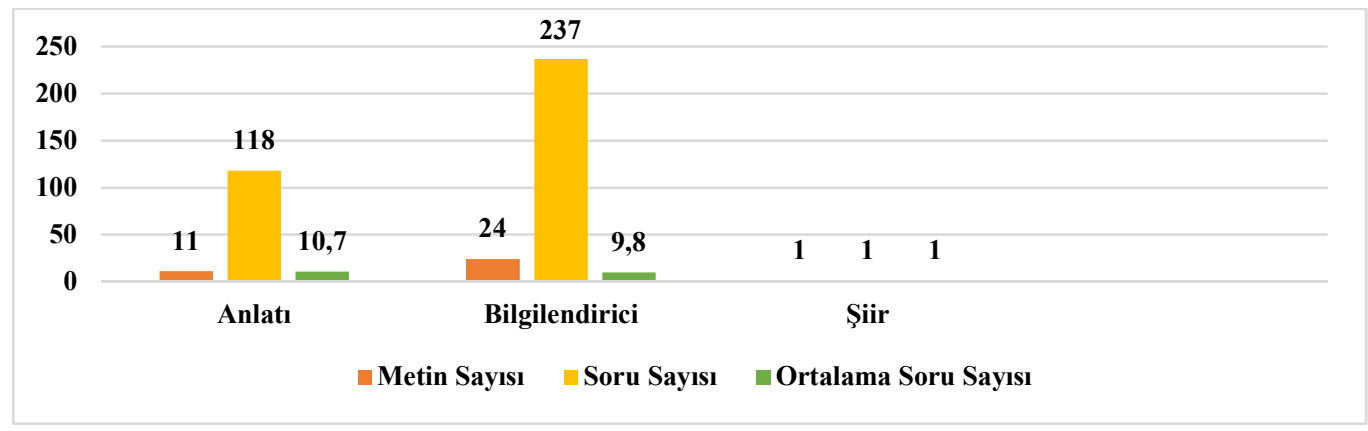

Şekil 7. İstanbul B2 ders kitabı metin türü ve soru sayısının dağılımı

Şekilde yer alan İstanbul Yabancılar İçin Türkçe B2 Ders Kitabı metin türü ve soru sayısı analizine bakıldığında anlatı türüne ait 11 metin ve bu 11 metne ait 118 soru tespit edilmiştir. Anlatı türündeki metinlerin ortalama soru sayısı ise 10.7 olmuştur. Bilgilendirici metin türünde bulunan 24 metin için toplam 237 soruya yer verilmiştir. Bilgilendirici metinlerin ortalama soru sayısı 9.8 'dir. Toplam 36 metin içerisinde yalnızca 1 metnin şiir türünde olduğu ve şiir metni için yalnız 1 soru verildiği görülmüş̧tür. Setin bu serisinde metinlerin bilgilendirici ağılıklı olduğu; ortalama soru sayılarına bakıldığında ise kısmen bir dengenin olduğu söylenebilmektedir. 
The analysis according to renewed Bloom taxonomy of the questions under the texts in the course books prepared for teaching Turkish as a foreign language / F. Kana, E. Z. Güney (pp. 141-161)

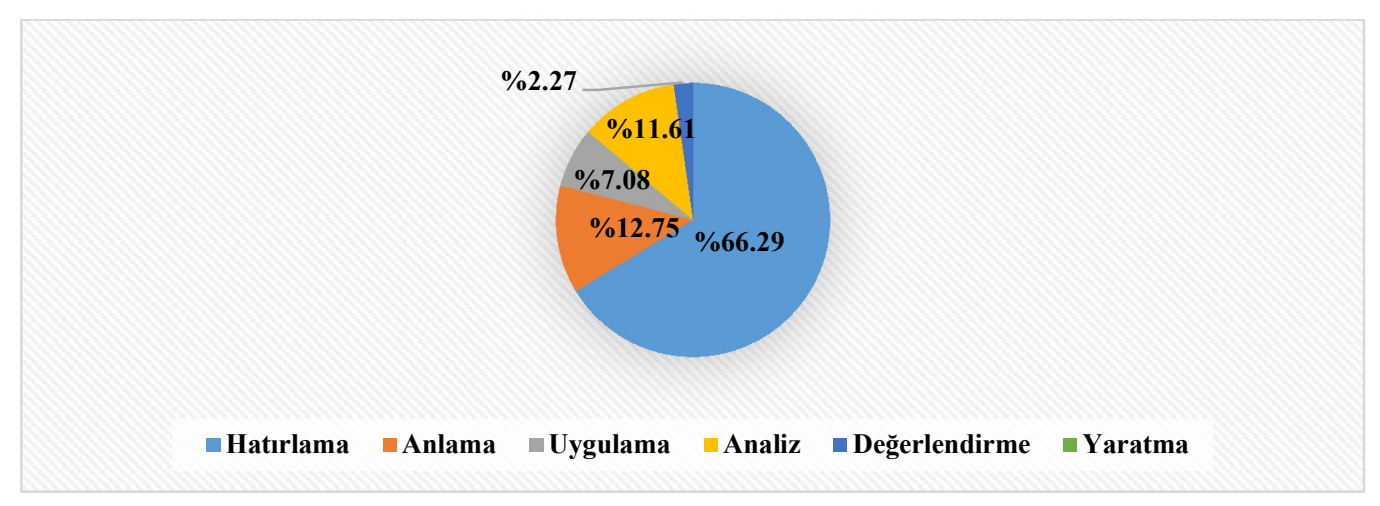

Şekil 8. İstanbul B2 ders kitabı metin altı soruların YBT’ye göre dağılımı

Şekil 3o'da İstanbul B2 Ders Kitabı okuma ve dinleme metinlerine ait metin altı soruların yenilenmiş Bloom taksonomisine göre yüzdelik dağılımı gösterilmektedir. Buna göre alt düzey bilişsel becerilerden hatırlama düzeyine ait soru yüzdesi \%66.29, anlama düzeyi \%12.75, uygulama düzeyi \%7.o8 olarak belirlenmiştir. Bulgulara bakıldığında hatırlama düzeyine ait soru yüzdesinin diğer kitaplarda olduğu gibi oldukça yüksek olduğu görülmektedir. Üst düzey bilişsel becerilerden analiz düzeyine ait soru yüzdesi \%11.61, değerlendirme düzeyi \%2.27 ve yaratma düzeyi \%o olarak belirlenmiştir. Buna göre üst düzey bilişsel becerilerden yalnız analiz düzeyine ait sorular bulunmaktadır denilebilir. Zira değerlendirme soru yüzdesi çok düşük tespit edilmiş, yaratma düzeyine dair soru örneğine ise rastlanılamamıştır. Elde edilen verilerin ışığında, B2 seviyesinden beklenilenin aksine bir tablo ile karşılaşıldığını söylemek mümkündür.

\section{İstanbul Yabancılar İçin Türkçe C1/+ Ders Kitabına İlişkin Bulgular ve Yorum}

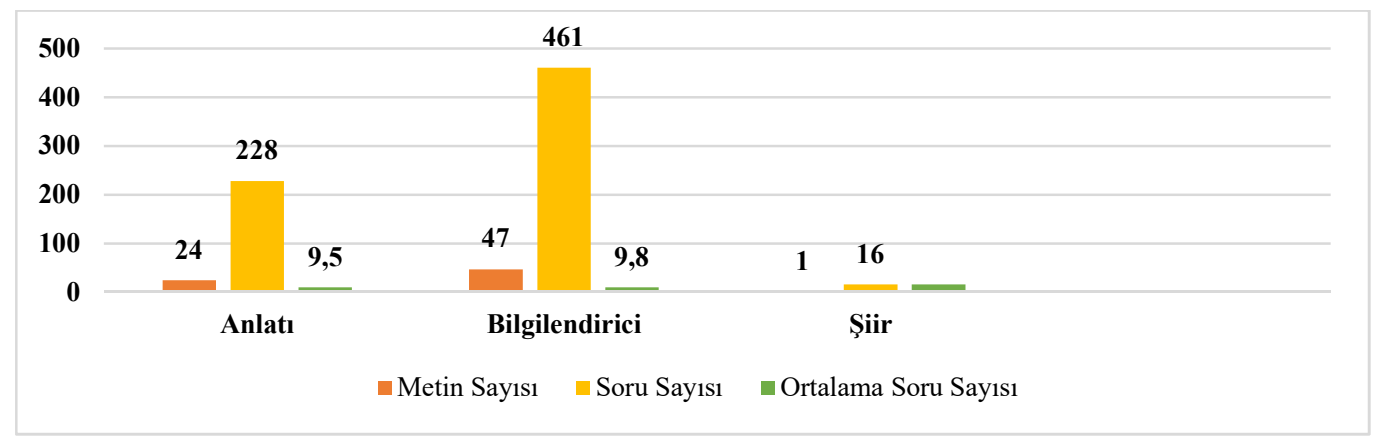

Şekil 9. İstanbul $C 1 /+$ ders kitabı metin türü ve soru sayısının dağılımı

İstanbul Yabancılar İçin Türkçe C1/+ Ders Kitabı metin türü ve soru sayısı dağılımına göre anlatı türüne ait 24 metin ve 228 soru tespit edilmiş, ortalama soru sayısı 9.5 olarak bulunmuştur. Bilgilendirici metin türünde bulunan 47 metin için toplam 461 soru bulunmaktadır. Ortalama soru sayısı ise 9.8 olarak görülmektedir. Şiir türünde yalnız 1 metin, metne ait 16 soru bulunmaktadır. Metnin soru sayısının fazla olması ortalamasının diğer metin türlerinden yüksek olmasına neden olmuştur. Kitabın ileri seviye olmasına bağlı olarak bilgilendirici türdeki metin sayısının fazla oluşu normal kabul edilmektedir. Ancak şiir türüne yalnız 1 metin ile yer verilmesi bulunulan seviyeye göre büyük bir eksiklik olarak göze çarpmaktadır. Metin sayısı ile soru sayısının yüksek olması diğer kitaplardan farklı olarak ilgili kitabın hem $\mathrm{C} 1$ hem de $\mathrm{C} 1+$ için kullanılması ile açıklanmaktadır. 


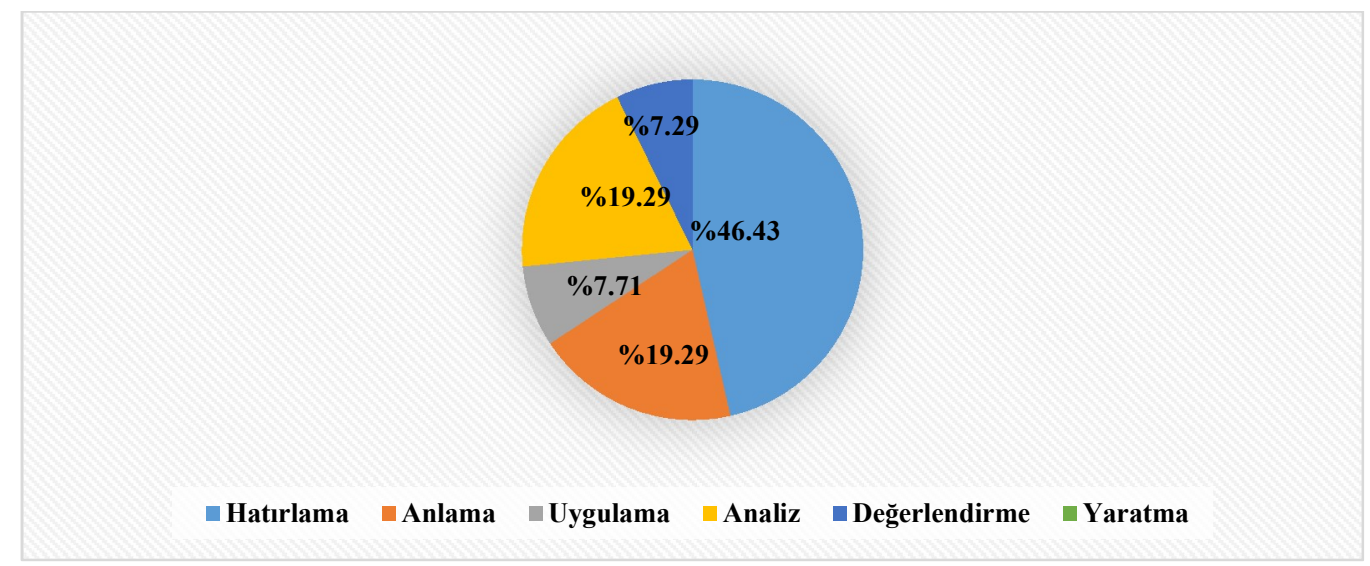

Şekil 10. İstanbul C1/+ ders kitabı metin altı soruların YBT’ye göre dağılımı

İstanbul Yabancılar İçin Türkçe C1/+ Ders Kitabı'nda bulunan metin altı soruların \%46.43’ü hatırlama düzeyini, \%19.29’u anlama düzeyini, \%7.71'i uygulama düzeyini, \%19.29’u analiz düzeyini, \%7.29’u değerlendirme düzeyini örneklendirmektedir. Yaratma düzeyine ilişkin soru örneği ise bulunmamaktadır. Şekle bakıldığında tüm seride olduğu gibi hatırlama düzeyi soru yüzdesinin fazla oluşu göze çarpmaktadır. Serinin sonuncusu olan ve öğrenmenin en yüksek seviyede gerçekleştiği kitapta elde edilen veriler soruların hazırlanmasında taksonomisinin esas alınmadığını ve soruların taksonomiye göre bir dağılım göstermediğini kanıtlar niteliktedir. Özellikle üst düzey bilişsel beceri olan değerlendirme ile yaratma basamağı soru yüzdeleri beklenenin tam tersi yönündedir.

\section{Yedi İklim Türkçe A1 ders kitabına ilişkin bulgular ve yorum}

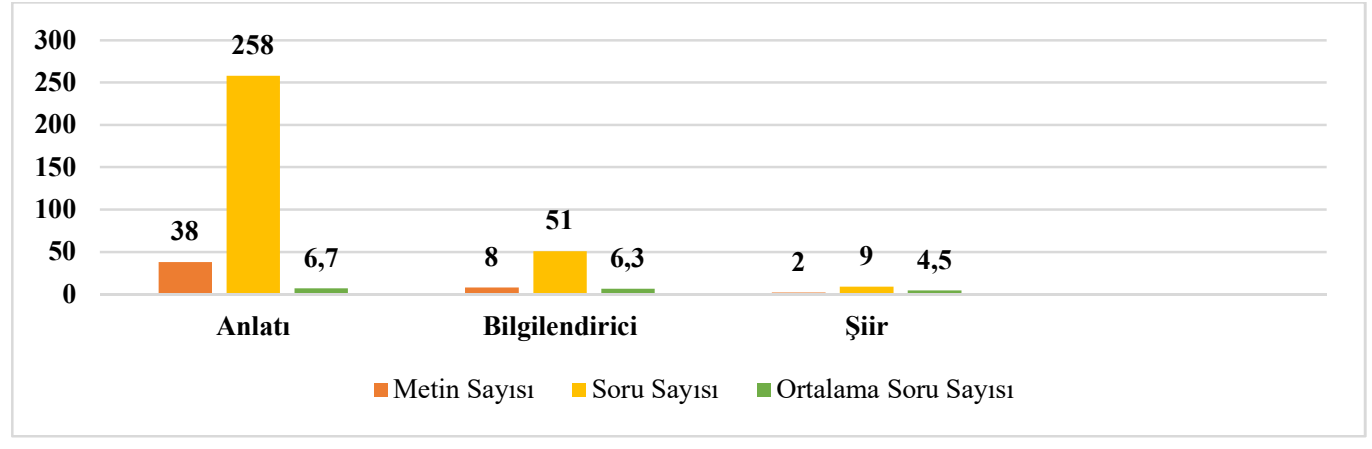

Şekil 11. Yedi İklim A1 ders kitabı metin türü ve soru sayısının dağılımı

Şekil 11'de yer alan $A 1$ Ders Kitabı metin türü ve soru sayısı dağılımına göre anlatı türünü örneklendiren 38 metin ve 258 soru tespit edilmiş, ortalama soru sayısı 6.7 olarak bulunmuştur. Bilgilendirici metin türünde bulunan 8 metne ait toplam 51 soru bulunmaktadır. Ortalama soru sayısı ise 6.3'tür. Şiir türünde 2 metin, metne ait 9 soru bulunmakta ve ortalama soru sayısı 4.5 olarak görülmektedir. İncelenen kaynağın A1 seviyesinde olduğu göz önüne alındığında anlatı metinlerinin sayıca fazla olması kabul edilebilir ancak anlatı metni ile bilgilendirici metin arasında ortaya çıkan fark oldukça fazladır. Metin türlerinin dağılımında her ne kadar dengesizlik göze çarpsa da A1 seviyesinde şiir türüne yer verilmiş olması dikkat çekmektedir. Yine soru ortalamalarına bakıldığında anlatı metinlerindeki 258 soruya ait $6.7^{\prime}$ 'lik ortalama ile bilgilendirici metinlerdeki 51 soruya ait 6.3 'lük ortalama soru sayısındaki dengesizliğin ispatıdır. 
The analysis according to renewed Bloom taxonomy of the questions under the texts in the course books prepared for teaching Turkish as a foreign language / F. Kana, E. Z. Güney (pp. 141-161)

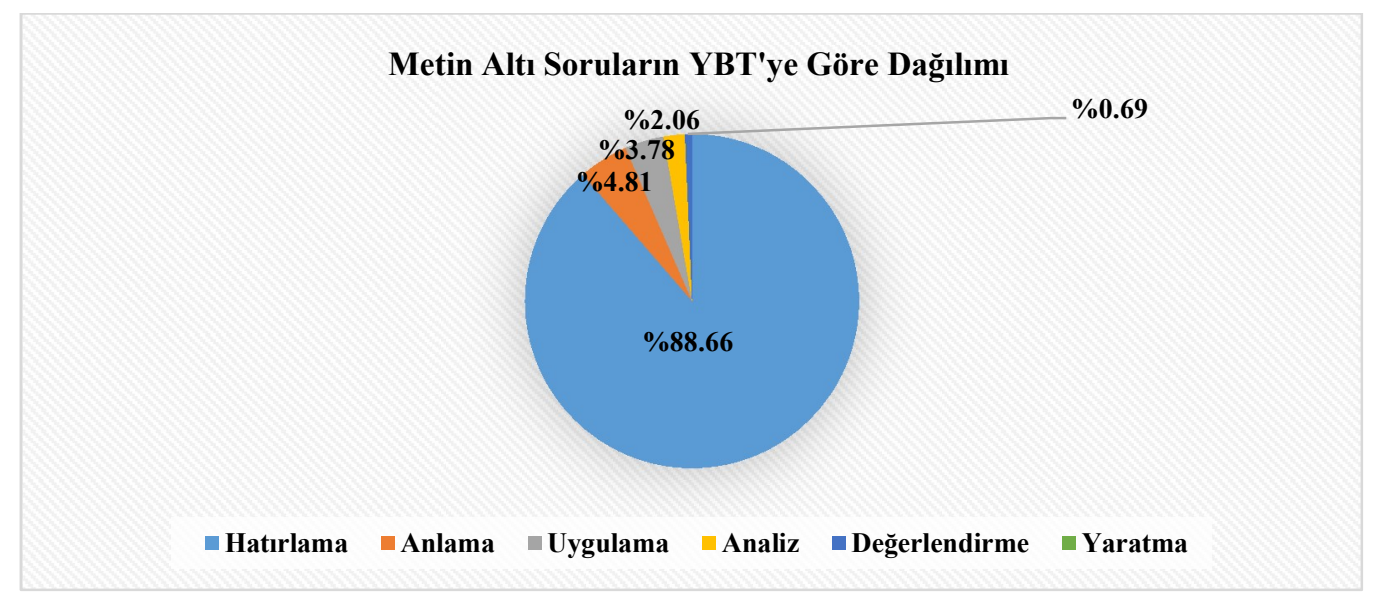

Şekil 12. Yedi iklim A1 ders kitabı metin altı soruların YBT’ye göre dağılımı

Yukarıdaki şekil incelendiğinde Yedi İklim A1 Ders Kitabı'nda bulunan metin altı sorulardan \%88.66'sının hatırlama, \%4.81'inin anlama, \%3.78'inin uygulama, \%2.06'sının analiz ve \%o.69'unun değerlendirme basamağına uygun olduğu görülmektedir. Yaratma basamağına ilişkin soru türüne ise rastlanılamamıştır. A1 seviyesi düşünüldüğünde hatırlama düzeyindeki soru yüzdesinin fazla olması normal karşılanmaktadır. Ancak elde edilen bulgulara bakıldığında hatırlama düzeyindeki soru yüzdesinin beklenenden fazla olduğu görülmektedir. Buna karşın, soruların basamak hiyerarşisine göre basitten zora doğru bir eğilim gösterdiği sonucuna varılabilir.

\section{A2 Ders kitabına ilişkin bulgular ve yorum}

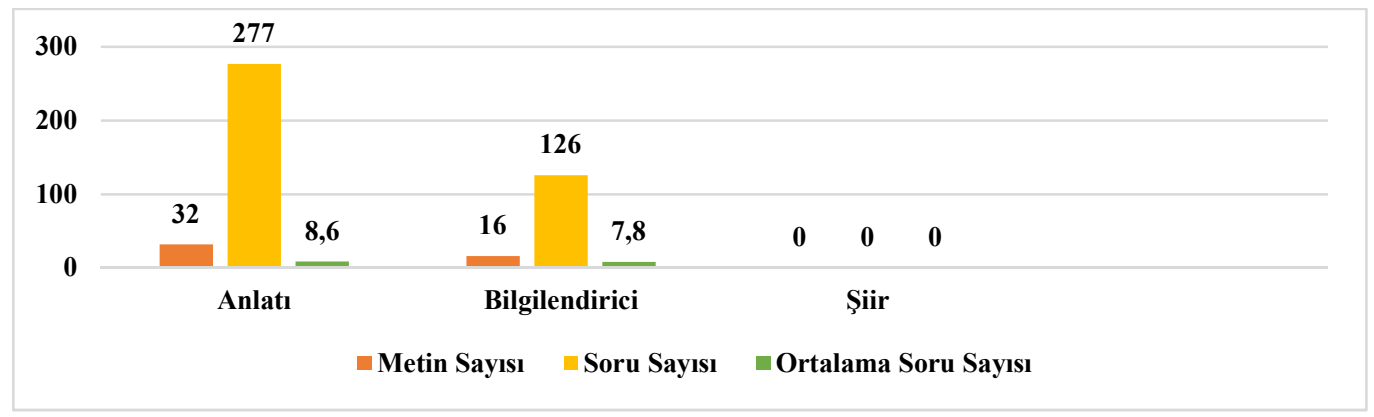

Şekil 13. Yedi iklim A2 ders kitabı metin türü ve soru sayısının dağılımı

Yukarıda yer alan şekle göre incelenen A2 ders kitabında anlatı türünde 32 metin ve 277 soru tespit bulunmaktadır. Bu türe ait ortalama soru sayısı 8.6 olarak bulunmuştur. Bilgilendirici metin türündeki 16 metne ait toplam 126 sorunun ortalaması 7.8 olarak tespit edilmiştir. Tema başında belirlenen okuma ve dinleme metinleri içerisinde şiir türünü örneklendiren metin bulunmamaktadır. Toplamda 48 metin içerisinde şiir türüne yer verilmemesi bir eksiklik olarak göze çarpmaktadır. Serinin A1 kitabında şiir türüne ait 2 metin olması buna rağmen A2 seviyesinde şïr türüne yer verilmemesi dikkate değerdir. Bir diğer önemli detay soru sayılarındaki dengesizliktir. Anlatı türündeki metinlerde bulunan metin altı soruların bilgilendirici metin sorularına göre daha az kaldığı ve bir dengenin olmadığı söylenebilmektedir. 


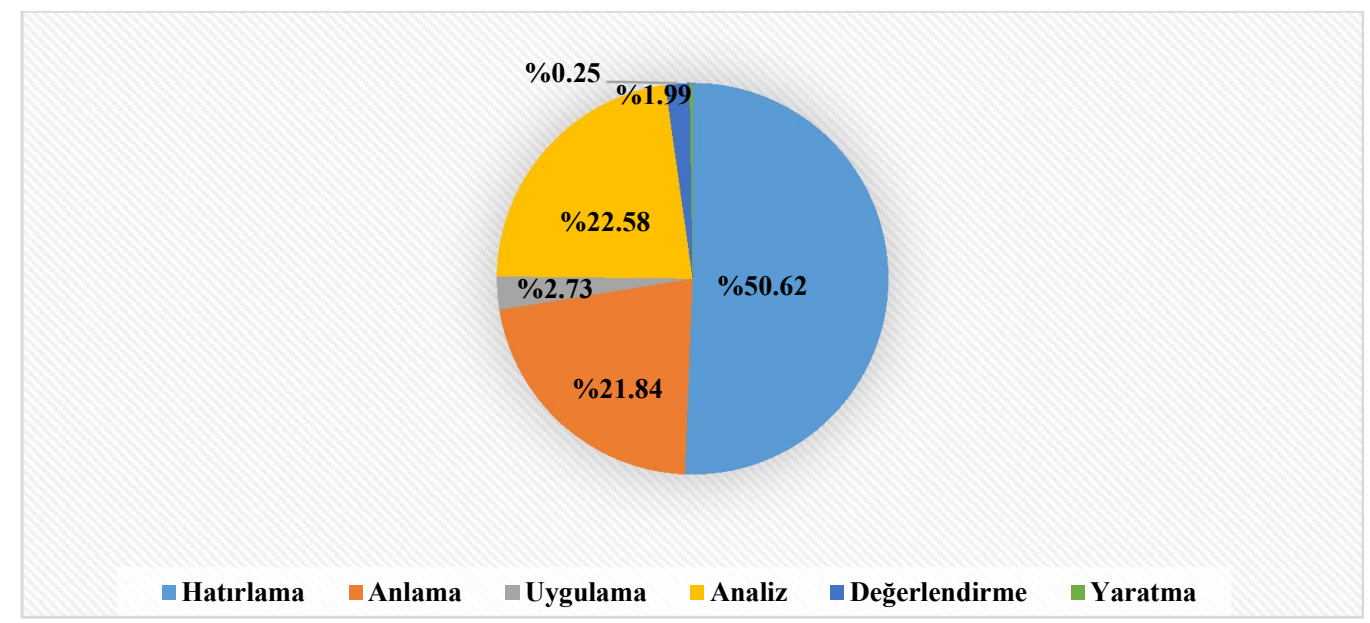

Şekil 14. Yedi iklim A2 ders kitabı metin altı soruların YBT’ye göre dağılımı

Şekil 14'e bakıldığında Yedi İklim A2 Ders Kitabı'nda bulunan metin altı soruların yenilenmiş taksonomiye göre yüzdeleri görülmektedir. Buna göre incelenen soruların \%50.62'si hatırlama düzeyindedir. Yüzdelik orana bakıldığında ilgili kitapta bulunan metin altı soruların yarısının hatırlama düzeyine ait olduğu görülmektedir. Anlama düzeyinde bulunan soru yüzdesi \%21.84, uygulama düzeyinde bulunan soru yüzdesi ise \%2.73’tür. Bu bağlamda alt düzey bilişsel basamakları örneklendiren soruların çok büyük çoğunluğunun hatırlama düzeyinde kaldığı özellikle de uygulamaya dönük soru yüzdesinin beklenenden az olduğu görülmektedir. üst düzey bilişsel basamak becerisi olan analiz düzeyindeki soru yüzdesi \%22.58, değerlendirme düzeyi \%1.99 ve yaratma düzeyi soru yüzdesi ise \%o.25 olarak tespit edilmiştir. Görüldüğü üzere üst düzey bilişsel becerileri örneklendiren soruların çoğunluğu analiz düzeyinde toplanmış ve değerlendirme ile yaratma basamağına dair soru yüzdesi yok denecek kadar az kalmıştır.

\section{B1 Ders kitabına ilişkin bulgular ve yorum}

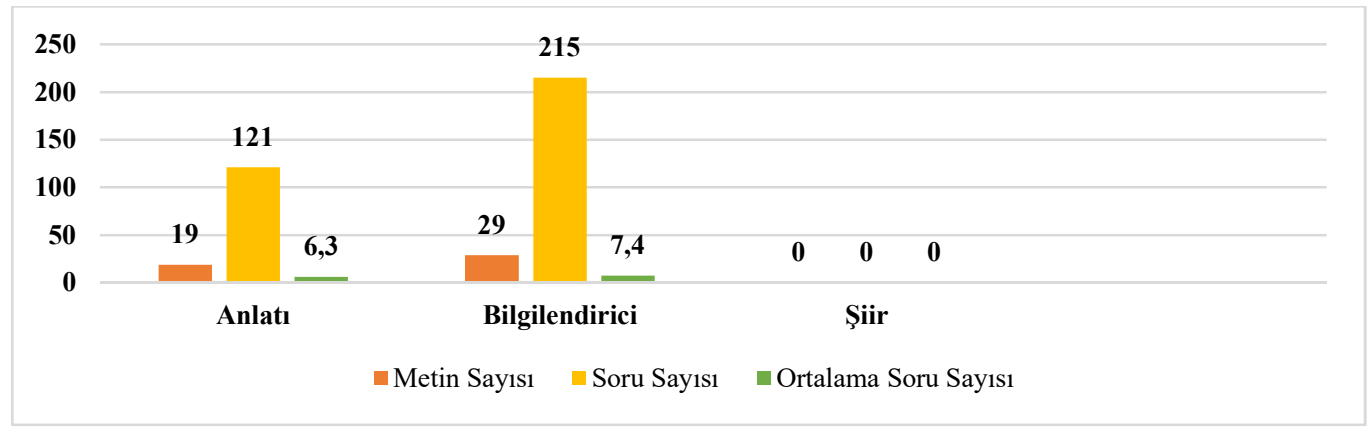

Şekil 15. Yedi iklim B1 ders kitabı metin türü ve soru sayısının dağılımı

Şekilde elde edilen bulgulara bakıldığında anlatı metin türünde 19 metin bulunmaktadır. Anlatı türündeki 19 metnin altında yer alan soru sayısı 121 ve ortalama soru sayısı ise 6.3 olarak tespit edilmiştir. Kitapta yer alan bilgilendirici metin sayısı 29'dur. Kitabın B1 seviyesinde olduğu düşünüldüğünde bilgilendirici metinlerin ağırlıkta olması normal karşılanmaktadır. Ancak şiir türüne ait metin bulunmaması eksikliktir. Bu durum yalnız tema başında belirlenen toplam 48 okuma ve dinleme metninin incelenmesi ile açıklanabilmektedir. Metin türlerinin dağılımında kısmen bir 
The analysis according to renewed Bloom taxonomy of the questions under the texts in the course books prepared for teaching Turkish as a foreign language / F. Kana, E. Z. Güney (pp. 141-161)

dengenin olduğu söylenebilmekte ancak bilgilendirici metin türüne ait metin altı soru sayısının anlatı metnine kıyasla daha az kaldı̆̆ı düşünülmektedir.

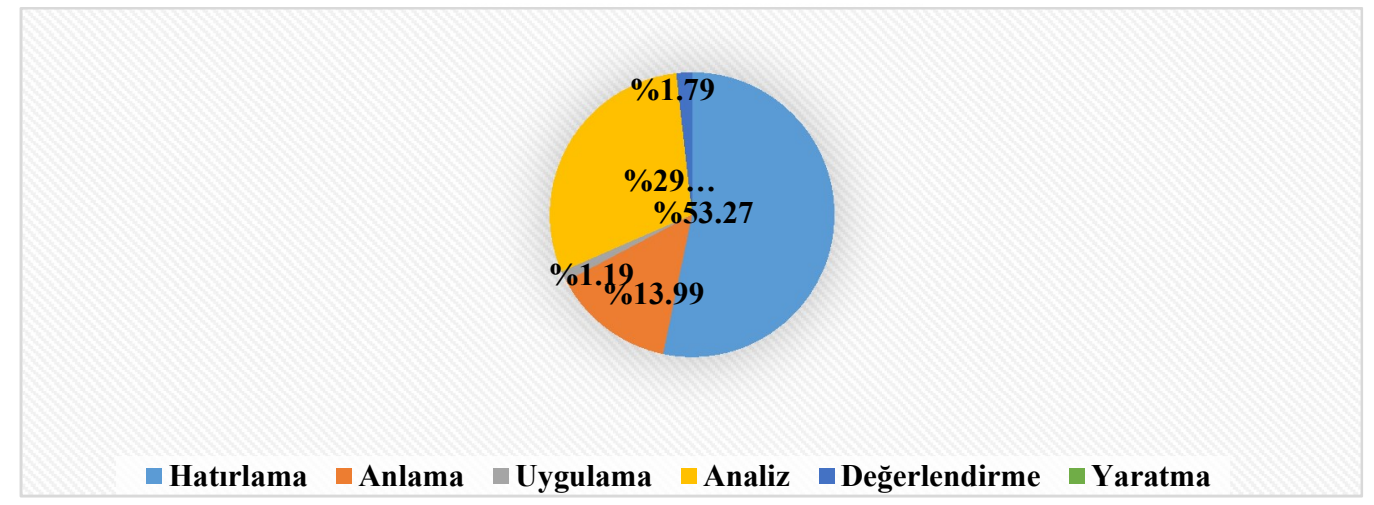

Şekil 16. Yedi iklim B1 ders kitabı metin altı soruların YBT’ye göre dağılımı

Şekil 16'da yer alan bulgulara bakıldığında Yedi İklim B1 Ders Kitabı’nda bulanan hatırlama düzeyindeki soru yüzdesinin \%53.27; anlama düzeyi soru yüzdesinin \%13.99; uygulama düzeyi soru yüzdesinin \%1,19; analiz düzeyi soru yüzdesinin \%29.76; değerlendirme düzeyi soru yüzdesinin \%1.79 ve yaratma düzeyi soru yüzdesinin ise \%o olduğı görülmektedir. Çıkan sonuçlara göre soruların yarısı hatırlama düzeyinde kalmıştır. Bu durum B1 ders kitabında beklenenin aksine bir sonuca ulaşıldığını göstermektedir. Öğrenilen bilgilerin uygulandığı soruların yok denecek kadar az olması ve bu düzeydeki öğrenciden cevaplayabilmesi beklenen değerlendirme ve yaratma düzeyindeki soruların azlığı/yokluğu dikkate değer bir eksikliğin olduğunu göstermektedir. Tüm bu bilgilerden hareketle tema başında belirlenen okuma ve dinleme metinlerindeki soruların hazırlanmasında bilişsel süreçlerin dikkate alınmadığı söylenebilmektedir.

\section{B2 Ders kitabına ilişkin bulgular ve yorum}

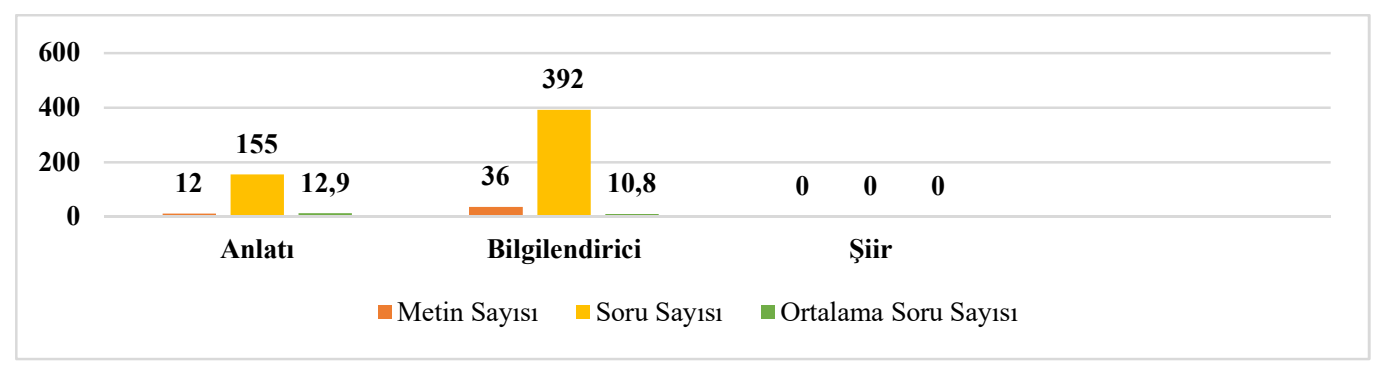

Şekil 17. Yedi iklim B2 ders kitabı metin türü ve soru sayısının dağılımı

Şekil 17'de göre anlatı türündeki metin sayısı 12 ve bu metne ait metin altı soru sayısı 155'tir. Anlatı türündeki metinlerde bulunan soruların ortalamasının 12.9 olduğu görülmektedir. bilgilendirici metin sayısı 36 olarak bulunurken bu türdeki metinlere ait soru sayısı 392 ve ortalama soru sayısı 10.8 olarak tespit edilmiştir. İncelenen okuma ve dinleme metinlerinde şiir türünde metin bulunmamaktadır. Öğrenme düzeyine bakıldığında öğrencilerde estetik bir duyuş ve zevk uyandıran şiir türünün olmayışı bir eksiklik olarak görülmektedir. Ancak bu durum yalnız tema başında belirlenen 48 metnin incelenmesi ile açıklanabilmektedir. Soruların dağılımına bakıldığında anlatı metin türünün tam üç katı sayıda olan bilgilendirici metinlerde bulunan soruların daha az olduğu görülmektedir. Bu bağlamda anlatı türüne göre anlaşılması daha zor olan bilgilendirici metinlerde öğrencilerin çok fazla soru ile 
yorulmak istenmediği düşünülmektedir. Ancak aksine metinlerin anlaşılmasının en iyi yolu metin altında bulunan sorulardır.

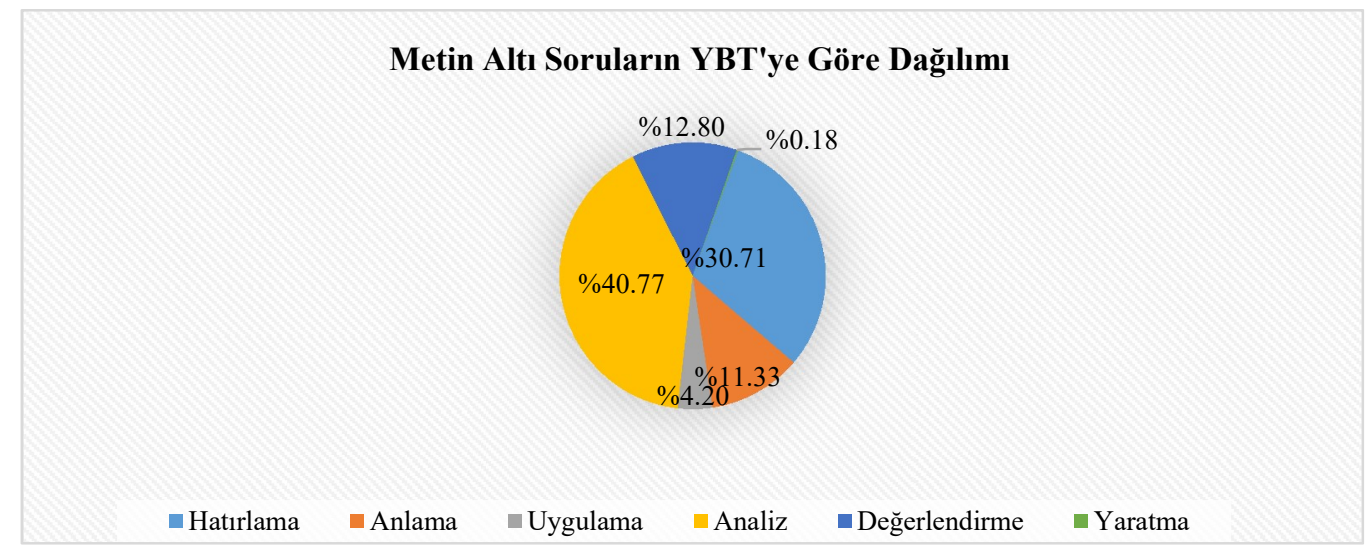

Şekil 18. Yedi iklim B2 ders kitabı metin altı soruların YBT’ye göre dağılımı

Yukarıdaki şekle göre, Yedi İklim B2 Ders Kitabında bulunan metin altı soruların \%30.71'i hatırlama düzeyi, \%11.33'ü anlama düzeyi, \%4.20'si uygulama düzeyi, \%40.77'si analiz düzeyi, \%12.80’i değerlendirme düzeyi ve \%o.18’i yaratma düzeyi sorularıdır. Elde edilen bulgulara bakıldığında alt düzey bilişsel basamak olan hatırlama düzeyi sorularının diğer alt düzey basamak olan anlama ve uygulama düzeyi sorulardan fazla olduğu göze çarpmaktadır. Gelinen B2 seviyesinde hatırlama düzeyi soru yüzdesinin bu denli yüksek olması beklenenin aksi bir sonuç çıktığını göstermektedir. Üst düzey bilişsel basamak sorularına bakıldığında analiz düzeyindeki soruların tüm sorular içerisinde en yüksek yüzdeye sahip olduğu görülmektedir. Serinin önceki kitapları ile kıyaslandığında değerlendirme düzeyi soru yüzdesindeki artış olumlu karşlanmaktadır. Ancak yaratma düzeyi sorularına yeteri kadar yer verilmediği de görülmektedir. Tüm bunlardan hareketle ilgili kitabın metin altı sorularında taksonominin basamaklarına göre daha dengeli bir dağılım olduğu söylenebilmektedir.

\section{C1 Ders kitabına ilişkin bulgular ve yorum}

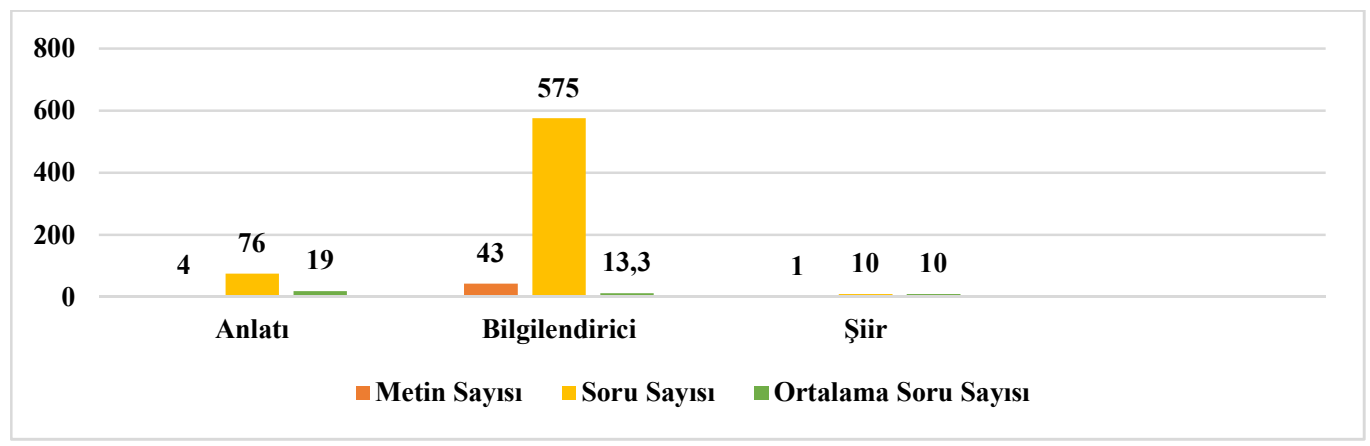

Şekil 19. Yedi iklim $C 1$ ders kitabı metin türü ve soru sayısının dağılımı

Şekil 41'den elde edilen bilgilere göre Yedi İklim C1 Ders Kitabı'nda bulunan toplamda 48 okuma ve dinleme metninin 4'ü anlatı metni, 43’ü bilgilendirici metin ve 1'i şiirdir. Metinlerin tür bakımından dağılımına bakıldığında bilgilendirici metinlerin ağırlıkta olduğu, anlatı metin sayısının oldukça düşük kaldığı, şiir türüne ise neredeyse hiç yer verilmediği görülmektedir. Bilgilendirici metin sayısının fazla oluşu incelenen kitabın C1 seviyesine ait olması ile açıklanabilmektedir. Ancak gelinen seviyede şiir 
The analysis according to renewed Bloom taxonomy of the questions under the texts in the course books prepared for teaching Turkish as a foreign language / F. Kana, E. Z. Güney (pp. 141-161)

türüne neredeyse hiç yer verilmemesi bir eksikliktir. Anlatı metinlerinin soru sayısı 76, ortalama soru sayısı 19; bilgilendirici metinlerin soru sayısı 575, ortalama soru sayısı 13.3 ve şiir metinlerinin soru sayısı 10, ortalama soru sayısı da 10 olarak tespit edilmiştir. Bilgilendirici metin sayısına bakıldığında soru sayısının olması gerekenden az olduğu göze çarpmaktadır. Bu durum anlatı metinlerine göre daha zor olması ve bu sebeple soru sayısının daha az tutulması ile açıklanabilmektedir.

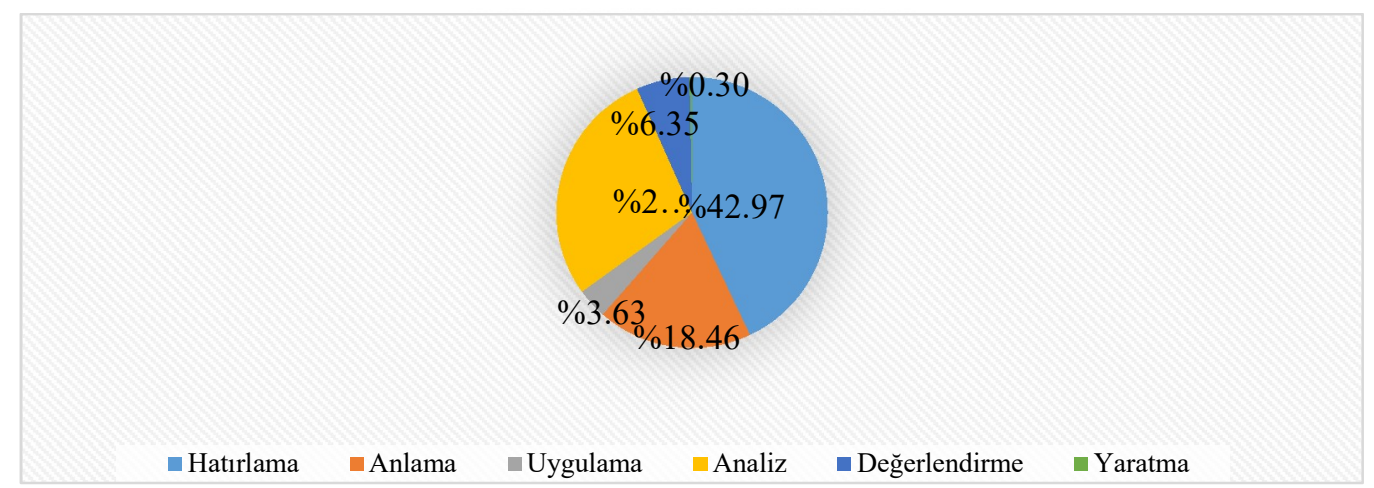

Şekil 2o. Yedi iklim C1 ders kitabı metin altı soruların YBT’ye göre dağılımı

Şekil 20’ye göre, incelenen Yedi İklim C1 Ders Kitabı'nda bulunan metin altı soruların yenilenmiş Bloom taksonomisine göre analizi şöyledir; hatırlama düzeyinde bulunan soruların yüzdesi \%42.97, anlama düzeyinde bulunan soruların yüzdesi \%18.46, uygulama düzeyinde bulunan soruların yüzdesi \%3.63, analiz düzeyinde bulunan soruların yüzdesi \%28.29, değerlendirme düzeyinde bulunan soruların yüzdesi \%6.35 ve yaratma düzeyinde bulunan soruların yüzdesi \%o,3o'dur. Genel dağılıma bakıldığında soruların neredeyse yarıya yakın oranda hatırlama düzeyine ait olduğu görülmektedir. Üst düzey bilişsel basamaklardan olan değerlendirme ve yaratma soruları çok az yüzdeye sahipken taksonominin en alt basamağı olan hatırlama basamağına uygun soruların bu kadar yüksek yüzdeye sahip olması soruların hazırlanmasında taksonominin dikkate alınmadığını göstermektedir. Özellikle gelinen seviyede yaratma düzeyi sorularına neredeyse hiç yer verilmemesi büyük bir eksiklik olarak görülmektedir.

\section{Yedi İklim Türkçe C2 ders kitabına ilişkin bulgular ve yorum}

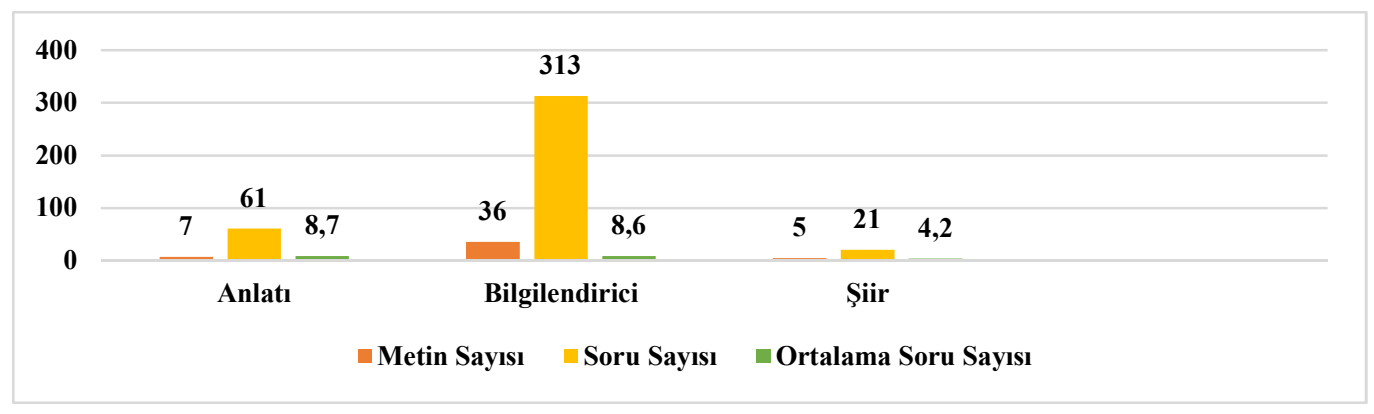

Şekil 21. Yedi iklim C2 ders kitabı metin türü ve soru sayısının dağılımı

Şekilde bulunan metin türü ve soru sayısının dağılımına göre anlatı türündeki metinlerin sayısı 7, bu metinlere ait toplam soru sayısı 61 ve her bir metin için ortalama soru sayısı 8,7 olarak tespit edilmiştir. Bilgilendirici metin sayısı 36, bu metinlere ait toplam soru sayısı 313 ve her bir metin için ortalama soru sayısı 8.6 olarak bulunmuştur. İlgili kitapta bulunan toplam 48 okuma ve dinleme metninin 5’i ise şiir türündedir. Şiir türüne ait metinlerde toplam 21 soru bulunmaktadır. Her bir metnin ortalama soru 
sayısı 4.2'dir. Metin türü dağılımına bakıldığında bilgilendirici metin sayısının diğer metin türlerine oranla yüksek olduğu görülmektedir. Ancak bilgilendirici metin türüne ait soru sayısının daha az olduğu, anlatı metinlerindeki soru ortalaması ile neredeyse aynı ortalamaya sahip olması ile kanıtlanabilmektedir. Serinin şiir türünü en fazla barındıran kitabı C2 Ders Kitabı olmuştur. Soru sayısının ise diğer kitaplara oranla düşük kaldığı görülmektedir. Bu durum metinlerin zorluk seviyesi ve uzunluğunun artması ile açıklanabilmektedir.

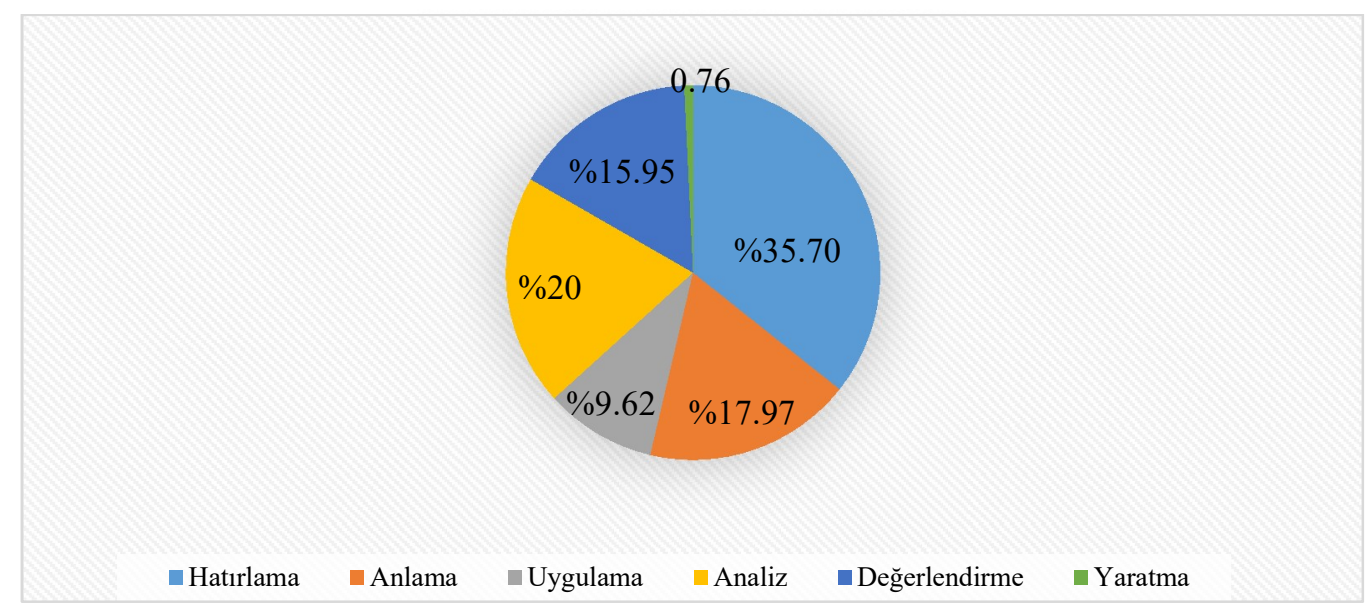

Şekil 22. Yedi iklim C2 ders kitabı metin altı soruların YBT’ye göre dağılımı

Şekil 22'ye göre, Yedi İklim C2 Ders Kitabı'nda bulunan metin altı soruların \%35.70’i hatırlama, \%17.97'si anlama, \%9.62'si uygulama, \%20'si analiz, \%15.95'i değerlendirme ve \%o,76's1 yaratma düzeyine aittir. Elde edilen bulguların ışığında, yaratma düzeyi hariç diğer basamak sorularında serinin diğer kitaplarına oranla nispeten dengeli bir dağılım görülmektedir. Ancak C2 seviyesine ait bir ders kitabında beklenen, soruların üst düzey bilişsel basamaklarda ağırlık göstermesidir. Özellikle yaratma basamağının serinin tüm kitaplarda çok düşük bir yüzdeye sahip olması, yaratma türünden soruların kitabın harici bölümlerde yazma ya da konuşma sorusu olarak öğrenciye sunulması ile ilgisi olduğu düşünülmektedir. Fakat metinlerin giderek zorlaşmasına bağlı olarak hem soru sayısının düşmesi hem de üst düzey bilişsel basamak sorularına daha az yer verilmesi metnin anlaşılmasını daha da zorlaştırabilecek bir etken olarak görülmektedir.

\section{Bölüm IV: Tartıșma, sonuç ve öneriler}

\section{Tartışma ve sonuç}

Araştırmanın bu bölümünde araştırmanın problem cümlesinden ve alt problemlerinden elde edilen sonuçlar alanyazında yapılan çalışmalar ele alınarak tartışılmıştır.

Araştırmanın birinci alt problemine ait tartışma ve sonuç. Yabancılara Türkçe öğretiminde kullanılan ders kitaplarındaki soruların seviyeye uygun bilişsel basamağı örneklendirip örneklendirmediğine ilişkin elde edilen bulgulara göre İstanbul Yabancllar İçin Türkçe A1 Ders Kitabı'nda bulunan 388 sorudan hatırlama düzeyine ait 259, anlama düzeyine ait 37, uygulama düzeyine ait 28, yaratma düzeyine ait 1 soru bulunmaktadır. Analiz düzeyini örneklendiren soru ile ise karşılaşılmamıştır. İstanbul Yabancılar İçin Türkçe A2 Ders Kitabı'ndaki 394 sorunun 310 tanesi hatırlama, 50 tanesi anlama, 14 tanesi uygulama, 18 tanesi analiz ve 2 tanesi değerlendirme düzeyine aittir. Yaratma düzeyine ait soru ise bulunmamaktadır. İstanbul Yabancılar İçin Türkçe B1 Ders 
The analysis according to renewed Bloom taxonomy of the questions under the texts in the course books prepared for teaching Turkish as a foreign language / F. Kana, E. Z. Güney (pp. 141-161)

Kitabı'na ait toplam 385 soru; 261 hatırlama, 40 anlama, 28 uygulama, 48 analiz ve 8 değerlendirme olacak şekilde dağılmıştır. İncelenen sorularda yaratma düzeyini örneklendiren soruya rastlanmamıştır. İstanbul Yabancllar İçin Türkçe B2 Ders Kitabı’nda tespit edilen 356 sorudan 234'ünün hatırlama, 45’inin anlama, 25’inin uygulama, 41’inin analiz ve 11’inin değerlendirme sürecini örneklendirdiği görülmektedir. İncelenen metinlerde yaratma düzeyine ait soru türü bulunmamaktadır. İstanbul Yabancılar İçin Türkçe C1/+ Ders Kitabı'nda bulunan 705 sorunun 325’i hatırlama, 135’i anlama, 54'ü uygulama, 135 ’ analiz, 51’i değerlendirme ve 5’i yaratma düzeyine aittir. Setin tüm kitaplarına genel olarak bakıldığında alt düzey bilişsel basamak olan hatırlama düzeyine ait soruların en fazla yüzdeye sahip olduğu görülmektedir. A1 kitabında hatırlama düzeyi soru yüzdesi \%66,75, A2'de \%78,68, B1'de $\% 67,79$, B2'de \%66,29 ve C1/+ kitabında \%46,43 olarak belirlenmiştir. Buna karşıllk üst düzey bilişsel basamak olan yaratma basamağı tüm kitaplarda en az yüzdeye sahiptir. Setin A1 kitabında yaratma düzeyi soru yüzdesi \%o,26, A2 kitabında \%o, B1 kitabında \%o, B2 kitabında \%o ve C1/+ kitabında da \%o olarak belirlenmiştir. Hatırlama düzeyine ait soruların giderek azalması ve yaratma düzeyini örneklendiren soruların yüzdesinde de giderek bir artış gözlenmesi beklenirken sonuçlar tam aksini göstermektedir

Yedi İklim Türkçe Yunus Emre Öğretim Seti’nde tema başında belirlenen okuma ve dinleme metinleri ile bu metinlere bağlı devam niteliğindeki metinler incelenmiştir. Elde edilen bulgulara göre A1 ders kitabında bulunan 318 sorudan 285'i hatırlama, 14'ü anlama, 11'i uygulama, 6'sı analiz ve 2'si değerlendirme basamağına ait olup yaratma basamağı ile ilgili soru bulunmamaktadır. Setin A2 ders kitabına bakıldığında okuma ve dinleme metinlerinin altında bulunan metin altı soruların toplamı 403'tür. Bu sorulardan 204'ü hatırlama, 88'i anlama, 11’i uygulama, 91’i analiz, 8’i değerlendirme ve 1 tanesi yaratma basamağına aittir. B1 ders kitabında bulunan metin altı soruların yenilenmiş Bloom taksonomisine göre analizinden elde edilen bulgulara göre toplamda 336 sorudan 179'u hatırlama, 47'si anlama, 4'ü uygulama, 100'ü analiz ve 6'sı değerlendirme basamağındadır. İncelenen metinlerde yaratma basamağını örneklendiren soruya ise rastlanılmamıştır. B2 ders kitabında bulunan 547 sorunun 168'i hatırlama, 62'si anlama, 23'ü uygulama, 223'ü analiz, 70’i değerlendirme ve 1'i yaratma basamağını örneklendirmektedir. Setin ileri seviye öğretim kitaplarının ilki olan C1 ders kitabında 661 metin altı sorusu tespit edilmiştir. Yapılan analize göre bu sorulardan hatırlama düzeyine ait 284, anlama düzeyine ait 122, uygulama düzeyine ait 24, analiz düzeyine ait 187, değerlendirme düzeyine ait 42 ve yaratma düzeyine ait 2 soru bulunmaktadır. Setin son kitabı olan C2 ders kitabı metin altı soru incelemesine göre kitapta yer alan toplam 395 sorunun 141'i hatırlama, 71'i anlama, 38’i uygulama, 79'u analiz, 63’ü değerlendirme ve 3’ü yaratma basamağına aittir. İncelenen öğretim setine bakıldığında, hatırlama düzeyine ait soruların ağırlıkta olduğu görülmektedir. A1 ders kitabında hatırlama düzeyine ait soru yüzdesi \%88.66, A2'de \%50.62, B1'de \%53.27, B2'de \%30.71, C1'de \%42.97 ve C2'de \%35.70'dir. Seviye göz önünde bulundurulduğunda hatırlama düzeyine ait soru yüzdesinin öğrenme düzeyinin artışına bağlı olarak azalması beklenmektedir. Halbuki yapılan incelemede hatırlama düzeyi soru yüzdesinde anlamlı ve düzenli bir düşüş görülmemektedir. Yaratma düzeyi soru yüzdelerine bakıldığında A1 ders kitabında \%o, A2'de \%o.25, B1'de \%o, B2'de \%o.18, C1'de \%o.3o ve C2'de 0.26'llk yüzdeye sahip olduğu belirlenmiştir. Beklenenin aksine öğrenme artışına bağlı olarak üst düzey bilişsel beceri sorularından olan yaratma basamağı soru yüzdesinde bir artış olmamış hatta düşüşler gözlenmiştir.

Barın ve Güzel (2013)'e göre, yabancılara Türkçe öğretiminde ilk düzeyden itibaren öğrenciler sözlü ve yazılı ifadeleri kullanmaya yöneltilmelidir. Ancak bu çalışmada yapılan inceleme sonucunda, her iki öğretim setinde de yer alan ders kitaplarındaki metin altı sorularının ağırlıklı olarak hatırlama basamağında yer aldığı görülmüştür. Hatırlama düzeyine yönelik soru sormaya yatkınlık, soru sorma 
teknikleri açısından birtakım sıkıntılara yol açmaktadır. Bu tür sorular "doğru” yanıt alma güvenliği sunsa da eleştirel düşünme için bir güvence vermezler (Oktay, 2015). Soruların düzeyi üst düzey düşünme seviyesini etkilemektedir. Olgulara dayalı bir soru, öğrencileri hatırlamaya ve ezber yapmaya yönlendirirken üst düzey düşünme gerektiren bir soru, öğrencileri edinmiş oldukları bilgileri kullanmaya ve bu bilgiler üzerine düşünmeye yönlendirir (Doğanay ve Ünal, 2006 akt. Aslan, 2011, s. 239). Ancak elde edilen bulgular incelenen ders kitaplarında üst düzey bilişsel becerileri harekete geçirecek soru sorma eğilimi olmadığını göstermektedir. Dolayısıyla yabancılara Türkçe öğretimi alanında kullanılan İstanbul Yabancılar İçin Türkçe ve Yedi İklim Türkçe öğretim setlerinde bulunan ders kitaplarındaki metin altı sorular seviyeye uygun bilişsel basamağı örneklendirmekten uzaktır.

Araştırmanın ikinci alt problemine ait tartışma ve sonuç. İncelenen İstanbul Yabancılar İçin Türkçe ve Yedi İklim Türkçe öğretim setlerinde bulunan ders kitaplarındaki metin türlerine bakıldığında İstanbul Yabancılar İçin Türkçe A1 Ders Kitabı metin türü dağılımına göre anlatı metin türünü örneklendiren 26, bilgilendirici metin türünü örneklendiren 9 metin ile karşılaşılmaktadır. Şiir türüne ait metin ise bulunmamaktadır. A2 ders kitabında bulunan toplam 36 metinden 23’ü anlatı, 13’ü bilgilendirici metin türündeyken şiir türüne ait metin bulunmamaktadır. B1 ders kitabına bakıldığında 14 anlatı, 22 bilgilendirici metin bulunmaktadır. Şiir türünü örneklendiren metne ise rastlanılamamıştır. B2 ders kitabından elde edilen bulgulara göre kitap içerisinde yer alan 36 metinden 11'i anlatı, 24'ü bilgilendirici metin türündedir. Önceki ders kitaplarından farklı olarak B2 ders kitabında 1 şiir metni bulunmaktadır. Setin son kitabı olan $\mathrm{C} 1 /+$ ders kitabında bulunan 72 metinden 24’ü anlatı, 47’si bilgilendirici metin türündedir. Ayrıca şiir türünde yalnız 1 metin bulunmaktadır. İstanbul Yabancılar İçin Türkçe Öğretim Seti’ne genel olarak bakıldığında seviye ilerledikçe anlatı metin türünde bir düşüş buna karşın bilgilendirici metin türünde ise bir artış gözlenmektedir. Şiir türüne ilk kez B2 ders kitabında rastlanmış olması ve hem $\mathrm{B} 2$ hem de $\mathrm{C} 1 /+$ ders kitaplarında yalnızca bir örneğinin bulunması bir eksiklik olarak görülmektedir. Özellikle yabancı dil öğretiminde roman, hikâye, masal gibi metinlere kıyasla şiir türüne daha az yer verilmektedir. Oysa şiir, her yaşta ve her dil seviyesinde yer alan öğrencinin ilgisini çekebilecek bir etki barındırmaktadır (Polat ve Dilidüzgün, 2015, s. 820). Set içerisinde yer alan metinlerin dağılımında da bir düzensizlik gözlenmektedir. Metin türleri sayıca karşlaştırıldığında bir tür ile diğer tür arasında oldukça fazla fark olduğu görülmüştür. "Türkçe ders kitapları için metin seçilirken tür çeşitliliğinin yanı sıra türe ilişkin metin sayısına dikkat edilmesi gerekmektedir. Öğrencilerin çeşitli eserleri okumasının yararları herkesçe bilinmektedir. Herhangi bir türden metnin özelliklerinin anlaşılabilmesi için öğrencilerin, o türdeki metinleri çokça okuması gerekmektedir" (Özbay ve Çeçen, 2012, s. 75).

Yedi İklim Türkçe Yunus Emre Öğretim Seti’ne bakıldığında A1 ders kitabında bulunan toplam 48 metinden anlatı metin türünde 38 , bilgilendirici metin türünde 8 ve şiir türünde 2 metin bulunmaktadır. A2 ders kitabında anlatı metin türünde 32, bilgilendirici metin türünde 16 metin bulunurken şiir türünü örneklendiren metne rastlanmamıştır. Orta seviye Türkçe kitaplarından olan B1 ders kitabında 19 anlatı metni, 28 bilgilendirici metin yer almaktadır. Kitapta şiir türünde metin bulunmamaktadır. B2 ders kitabı metin türü incelemesine göre kitap içerisinde yer alan okuma ve dinleme metinlerinden 12'si anlatı, 36'sı bilgilendirici metin türünde bulunmaktadır. İncelenen metinlerde ise şiir türünün örneği ile karşılaşılmamıştır. İleri seviye kitapları olan $\mathrm{C} 1$ ve C2 kitaplarına bakıldığında C1 ders kitabında 4 anlatı, 43 bilgilendirici ve 1 şiir türü; C2 ders kitabında ise 7 anlatı, 36 bilgilendirici ve 5 şiir türünde metin bulunmaktadır. İstanbul Yabancılar İçin Türkçe seti ile karşılaştırmalı olarak bakıldığında Yedi İklim Türkçe setinde de seviye ilerledikçe anlatı türündeki metinlerin sayısında düşüş ve bilgilendirici metinlerin sayısında artış gözlenmektedir. Her bir kitapta metin türleri arasında sayıca yüksek bir fark olduğu bu set için de söylenebilmektedir. Şiir türüne yeteri kadar yer verilmemesi ise kitapta bulunan 
The analysis according to renewed Bloom taxonomy of the questions under the texts in the course books prepared for teaching Turkish as a foreign language / F. Kana, E. Z. Güney (pp. 141-161)

metinlerden yalnızca tema başında belirtilen metinlerin incelemeye alınması ve her bir temada bulunan harici metinlerin işe koşulmaması ile açıklanabilmektedir.

\section{Öneriler}

Yapılan çalışmadan elde edilen bulgulara göre yabancılara Türkçe öğretimi alanında kullanılan öğretim setlerinde bulunan metin altı soruların yenilenmiş Bloom taksonomosine göre hiyerarşik ve seviyeye uygun şekilde yer almadığı görülmüştür. Sorular hazırlanırken seviye göz önünde bulundurularak bilişsel basamaklara uygun sorular hazırlanmasına dikkat edilebilir.

Her bir metin için hazırlanan sorularda bilişsel basamakların hiyerarşik şekilde sıralanmadığı ve çeşitlilik göstermediği, çoğunlukla tek bir bilişsel basamağa hizmet eden sorulara yer verildiği görülmüştür. Oysa tek bir metne ait sorular hazırlanırken kolaydan zora ilkesi gözetilerek bilişsel basamaklara hiyerarşik şekilde yer verilebilir.

İncelenen setlerin ders kitaplarında özellikle üst düzey bilişsel basamak soruların azlığı dikkat çekmektedir. Halbuki üst düzey bilişsel basamak olan analiz, değerlendirme ve yaratma becerileri öğrencilerin dili öğrenme ve etkin kullanma sürecine alt düzey basamak becerilerine göre daha fazla hizmet etmektedir. Bu bağlamda alt seviye öğretim kitaplarından itibaren üst düzey bilişsel basamak sorularına daha fazla yer verilmelidir.

Metin türleri incelemesine bakıldığında türsel çeşitliğin olmadığı ve özellikle anlatı metinleri ile bilgilendirici metinler arasında her kitapta sayıca ciddi farklar olduğu görülmüştür. Yabancılara Türkçe öğretimi kitapları hazırlanırken türlerin dengeli dağılmasına dikkat edilmeli, türünün en güzel örnekleri sunulmalıdır.

\section{Kaynakça}

Aksan, D. (1998). Her yönüyle dil ana çizgileriyle dilbilim. Ankara: TDK.

Arı, A. (2011). Bloom'un gözden geçirilmiş bilişsel alan taksonomisinin türkiye'de ve uluslararası alanda kabul görme durumu. Kuram ve Uygulamada Ĕ̆itim Bilimleri, 11(2), 749-772.

Arı, A. (2013). Bilişsel Alan Sinıflamasında Yenilenmiş Bloom, SOLO, Fink, Dettmer Taksonomileri ve Uluslararası Alanda Tanınma Durumları. Uşak Üniversitesi Sosyal Bilimler Dergisi, 13.

Aslan, C. (2011). Soru sorma becerilerini geliştirmeye dönük öğretim uygulamalarının öğretmen adaylarının soru oluşturma becerisine etkisi. Eğitim ve Bilim Dergisi, 36 (160), 236- 249.

Barın, E. ve Güzel, A. (2013). Yabancı dil olarak Türkçe öğretimi. Ankara: Akçă̆ .

Bekdemir, M. ve Selim, Y. (2008). Revize edilmiş Bloom taksonomisi ve cebir öğrenme alanı örneğinde uygulaması. Erzincan Eğitim Fakültesi Dergisi, 1o(2), 185-196.

Bölükbaş, F. ve Keskin, F. (2010). Yabancı dil olarak Türkçe öğretiminde metinlerin kültür aktarımındaki işlevi. Turkish Studies, 5(4), 221-235.

Büyüköztürk, Ş., Çakmak, K. E., Akgün, Ö. E., Karadeniz, Ş. ve Demirel, F. (2014). Bilimsel araştırma yöntemleri (13. baskı). Ankara: Pegem Akademi.

Demirel, Ö. (1993). Yabancı dil öğretimi ilkeler, yöntemler, teknikler (3. Basım). Ankara: Usem.

Durukan, E. ve Demir, E. (2017). 6, 7 ve 8. sınıf Türkçe dersi öğrenci çalışma kitaplarındaki etkinliklerin bloom'un yenilenmiș taksonomisine göre sınıflandırılması. Uluslararası Türkçe Edebiyat Kültür Ĕgitim Dergisi, 6(3), ss. 1619-1629.

Erol, H. F. (2014). Yabancı Dil Olarak Türkçe Ders Kitaplarında Okunabilirlik. Türk Dili ve Edebiyatı Dergisi, 50, 29-38. 
Glesne, C. (2012). Nitel araştırmaya giriş (Çev. Ed: A. Ersoy ve P. Yalçınoğlu). Ankara: Anı.

Göçer, A. (2007). Türkçenin yabancı dil olarak öğretiminde kullanılan ders kitaplarının ölçme ve değerlendirme açısından incelenmesi. Dil Dergisi, 137, 30-46.

Gün, M., Akkaya A. ve Kara, Ö.M. (2014). Yabancılara Türkçe öğretimi ders kitaplarının Türkçe öğretim merkezlerinde görev yapan öğretim elemanları açısından değerlendirilmesi. Turkish Studies, $9(6), 1-16$.

Günay, V. D. (2007). Metin bilgisi. İstanbul: Multilingual.

Güneş, F. (2013). Türkçe öğretimi yaklaşımlar ve modeller. Ankara: Pegem Akademi.

Güneş, F. (2013). Türkçe öğretiminde metin seçimi. Ana Dili Eğitimi Dergisi. 1(1), 1-12.

Halis, İ. (2002). Öğretim teknolojileri ve materyal geliştirme. Ankara: Nobel.

İstanbul Üniversitesi Dil Merkezi (2018). İstanbul Yabancılar İçin Türkçe Ders Kitapları (A1, A2, B1, B2, $\mathrm{C} 1, \mathrm{C} 1+)$. İstanbul.

İşcan, A. (2012). Yabancı dil öğretimi ve yabancı dil olarak Türkçe öğretiminin tarihçesi. Ankara: Pegem Akademi.

Korkmaz, F. ve Ünsal S. (2016). Bloom’un yenilenmiș taksonomisine göre bir sınav analizi. Turkish Journal of Education, 5(3).

Kuzu. T. S. (2013). Türkçe ders kitaplarındaki metin altı sorularının yenilenmis bloom taksonomisindeki hatırlama ve anlama bilişsel düzeyleri açısından incelenmesi. $C \dot{U}$ Sosyal Bilimler Dergisi, 37(1), 58-76.

Küçükahmet, L. (2003). Konu alanı ders kitabı inceleme kılavuzu. Ankara: Nobel.

Oktay, M. R. (2015). Yabancllara Türkçe öğretimi ders kitaplarındaki metin alt s sorularmın bloom taksonomisindeki bilişsel düzeyler açısından incelenmesi. Yayımlanmamış Yüksek Lisans Tezi. Ankara Üniversitesi, Ankara.

Onursal, İ. (2003). Türkçe metinlerde bağdaşıklık ve tutarlılık. A. Kıran, E. Korkut, S. Ağıldere (Ed.), Günümüz Dilbilim Çalışmaları (ss. 121-132). İstanbul: Multilingual.

Özbay, M. (2002). Kültür Aktarımı Açısından Türkçe Öğretimi. Türk Dili Dergisi, 602, 112-120.

Özbay, M. ve Çeçen, M. A. (2012). Türkçe Ders Kitaplarında (6-8. Sınıflar) Yer Alan Metinlerin Tür ve Tema Açısından İncelenmesi. Dil ve Edebiyat Eğitimi Dergisi, 1(1), 67-76

Polat, Ö.S. ve Dilidüzgün Ş. (2015). Yabancı dil olarak Türkçe öğretiminde şiir etkinliklerinin kültürel işlevi. Turkish Studies, 10(7), 815-834.

Sönmez, V. (2007). Program geliştirmede öğretmen el kitabı. Ankara: Anı.

Toprak, F. (2011). Yabancılara Türkçe öğretimi kitaplarındaki okuma parçaları ve diyalogları üzerine bir değerlendirme. Selçuk Üniversitesi Türkiyat Araştırmaları Dergisi, 29, 11-24.

Yaşar, F. (2018). Yabancı dil olarak Türkçe öğretiminde ölçme ve değerlendirme. A.Şahin (Ed.), Yabancı Dil Olarak Türkçe Öğretimi (ss.619-653). Ankara: Pegem Akademi

Yıldırım, A. ve Şimşek, H. (2008). Sosyal bilimlerde nitel araştırma yöntemleri. Ankara: Seçkin.

Yunus Emre Enstitüsü (2019). Yedi iklim Türkçe öğretim Seti (A1, A2, B1, B2, C1, C2). https://www.yee.org.tr/tr/yayinlar/dersmateryalleri/yedi-iklim-turkce Erişim Tarihi: 20.06.2018 